\title{
Twenty of the most thermophilous vascular plant species in Svalbard and their conservation state
}

\author{
Torstein Engelskjøn, Leidulf Lund \\ \& Inger Greve Alsos
}

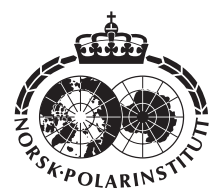

An aim for conservation in Norway is preserving the Svalbard archipelago as one of the least disturbed areas in the Arctic. Information on local distribution, population sizes and ecology is summarized for 20 thermophilous vascular plant species. The need for conservation of northern, marginal populations in Svalbard is reviewed, using World Conservation Union categories and criteria at a regional scale. Thirteen species reach their northernmost distribution in Svalbard, the remaining seven in the western Arctic. Nine species have 1-8 populations in Svalbard and are assigned to Red List categories endangered or critically endangered: Campanula rotundifolia, Euphrasia frigida, Juncus castaneus, Kobresia simpliciuscula, Rubus chamaemorus, Alchemilla glomerulans, Ranunculus wilanderi, Salix lanata and Vaccinium uliginosum, the last four species needing immediate protective measures. Five species are classified as vulnerable: Betula nana, Carex marina ssp. pseudolagopina, Luzula wahlenbergii, Ranunculus arcticus and Ranunculus pallasii. Six species are considered at lower risk: Calamagrostis stricta, Empetrum nigrum ssp. hermaphroditum, Hippuris vulgaris (only occurring on Bjørnøya), Juncus triglumis, Ranunculus lapponicus and Rhodiola rosea. The warmer Inner Arctic Fjord Zone of Spitsbergen supports most of the 20 target species and is of particular importance for conservation. Endangered or vulnerable species were found in a variety of edaphic conditions; thus, several kinds of habitats need protection.

T. Engelskjøn, I. G. Alsos, Tromsø Museum, University of Tromsø, NO-9037Tromsø, Norway, torstein@ tmu.uit.no; L. Lund, Phytotron, University of Tromsø, NO-9037 Tromsø, Norway.

The archipelago of Svalbard $\left(74^{\circ} 20^{\prime}-80^{\circ} 50^{\prime} \mathrm{N}\right)$ (Fig. 1) is one of the world's least impacted Arctic biomes, and it is an aim for Norwegian authorities to preserve it (Stortinget 2000). A plan for vegetation protection has been proposed by the Governor of Svalbard (1999; see Alsos 2000) because the prevailing practice of protecting plant species, but not their habitats, had evident shortcomings (Theisen \& Brude 1998; Alsos 2000). The new plan (Miljøverndepartementet 2003) is a supplement to the national park system of Svalbard and implies protection of all plant life within circum- scribed geographical areas (Fig. 2).

Svalbard harbours approximately 165 native vascular plant species (Elven \& Elvebakk 1996). The Inner Arctic Fjord Zone of Spitsbergen (Fig. 1) is particularly rich in species and is favoured by frequently clear skies and elevated summer temperatures (Elvebakk 1985, 1989).

Between 20 and 30 of Svalbard's vascular plant species can be considered warmth-demanding compared to the rest of the archipelago's flora (Engelskjøn 1987; Elvebakk 1989). Their few, small and disjunct present-day populations are 


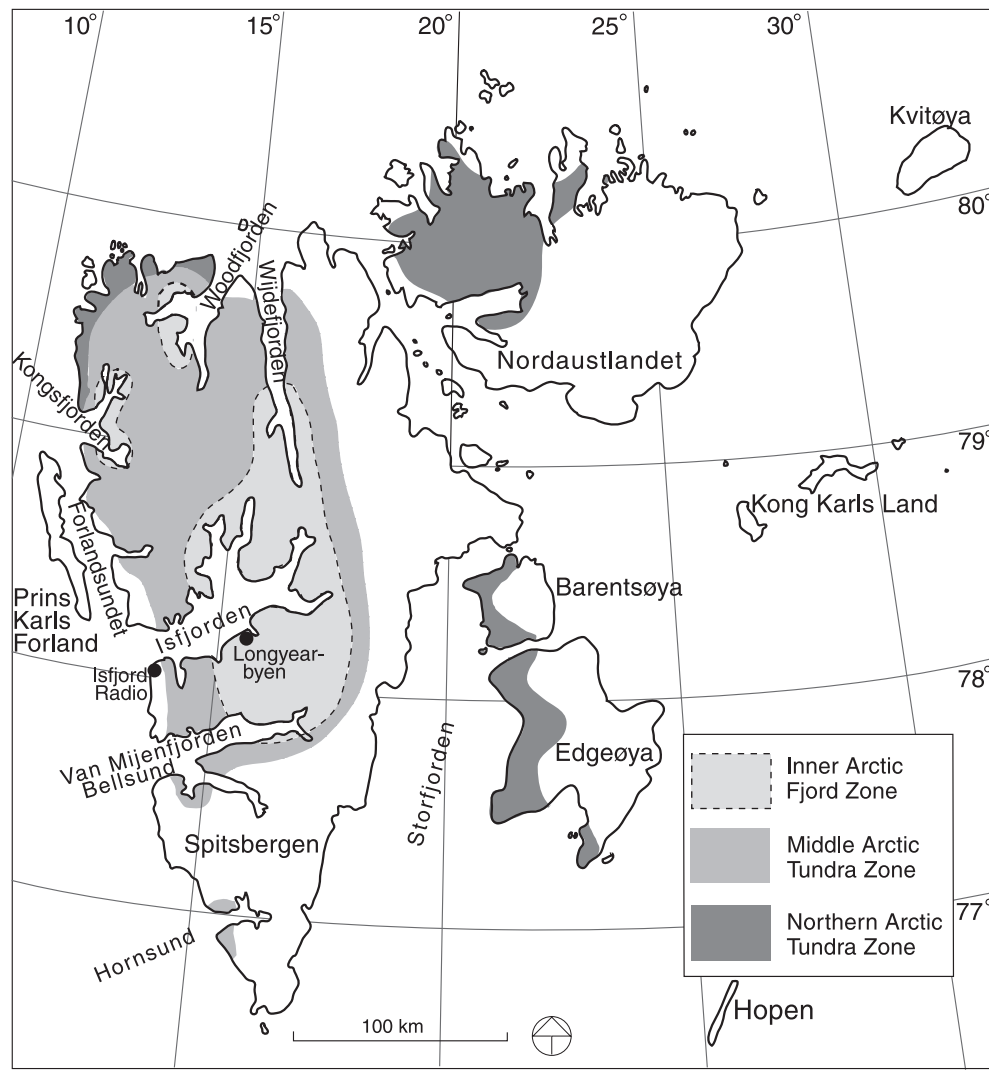

Fig. 1. Vegetation zones of Svalbard, adapted from Möller (2000). (The small island of Bjørnøya, about $250 \mathrm{~km}$ south of the main groups of islands, is not shown.)

partly relicts of larger populations thought to have been established between 9000 and 4000 years ago, when the mean July temperature was $1-2{ }^{\circ} \mathrm{C}$ higher than at present (Birks 1991). The temperature decline over the last 4000 years (Birks 1991) may have suppressed sexual reproduction and caused fragmentation of populations and genetic bottlenecks (Alsos, Brochman et al. 2002; Alsos et al. 2003). Several thermophilous species rarely produce germinable seeds under the present climatic conditions and may thus have a reduced recruitment following disturbance (Nathorst 1883; Alsos et al. 2003; Cooper et al. in press). Increased human activity in the most species-rich parts of Svalbard (Hansen et al. 1996; Theisen \& Brude 1998) may constitute a threat to the thermophilous species of the archipelago.

Many records of these species are more or less buried in the literature. Plant records prior to Hadač (1944) were imprecise due to lack of topographical maps. In spite of Svalbard having been frequently visited, documentation of uncommon species tended to be anecdotal. This paper is based on botanical surveys of Bjørnøya (Engelskjøn \& Schweitzer 1970; Engelskjøn 1987), parts of Spitsbergen (Engelskjøn et al. 1972; Hofmann \& Thannheiser 1972; Thannheiser 1972; Dubiel 1990; Kuc \& Dubiel 1995; Elven et al. 1990; Möller \& Thannheiser 1997; Möller 2000; Alsos, Lund et al. 2002), Nordaustlandet (Neilson 1968), Edgeøya (Neilson 1970), Barentsøya (Hjelmstad 1981) and Svalbard as a whole (Elvebakk 1985, 1989; Engelskjøn 1986; Elven \& Elvebakk 1996), as well as our recent field investigations.

Our aim is to assess the local distribution of 20 target species in relation to their presumed edaphic and thermal demands and their need of conservation measures to protect them. Also considered are the southern geographical range extensions of some of these species and their mainly low alpine altitudinal limits in northern Scandinavia (Engelskjøn 1986, 1994).

Twenty thermophilous vascular plant species in Svalbard 
Fig. 2. Extant and proposed protected areas (national parks and nature reserves, excluding bird reserves) in Svalbard, excluding Bjørnøya. Redrawn after Governor of Svalbard (1999) and Miljøverndepartementet (2003).

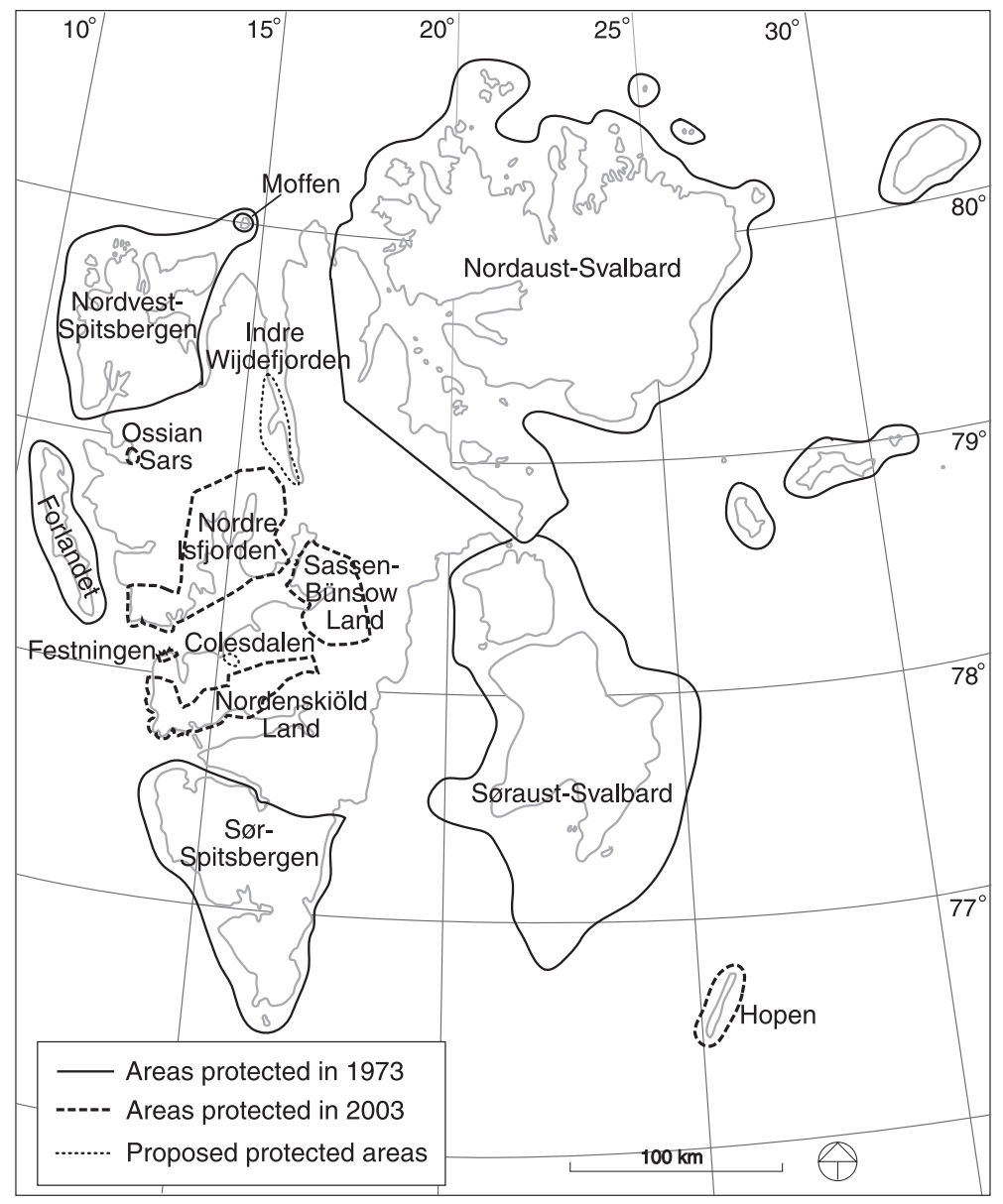

\section{Study area}

Svalbard is subdivided into provinces shown in Fig. 3. Also a part of the archipelago is the small island of Bjørnøya, about midway between the Norwegian mainland and the island of Spitsbergen.

\section{Methods}

\section{Inclusion of species}

Apart from the 20 species treated here, at least 11 other vascular plant species in Svalbard may be considered thermophilous, e.g. Arctagrostis latifolia (Rønning 1972), Botrychium boreale, B. lunaria (Elvebakk et al. 1994), Arenaria humifusa, Carex glacialis (Elven \& Elvebakk
1996), Carex bigelowii (Elven \& Elvebakk 2002), Cystopteris fragilis (Rønning 1972), Gentianella tenella (Elvebakk 1989), Juncus arcticus (Lid 1925, 1967), Taraxacum brachyceras (Elvebakk 1989) and Tofieldia pusilla (Rønning 1972). However, these rare species were insufficiently documented or not seen by us.

Conversely, at least two very rare species in Svalbard are adapted to cold conditions, viz. Ranunculus glacialis (Elven \& Elvebakk 1996) and Sagina caespitosa (Lid 1962).

\section{Phytogeographical terms}

Zonal subdivision of Svalbard follows Möller (2000: 43) with respect to the Inner Arctic Fjord Zone of Spitsbergen (Fig. 1). In a circum-Arctic context we use the phytogeographical terms presented in Table 1. 


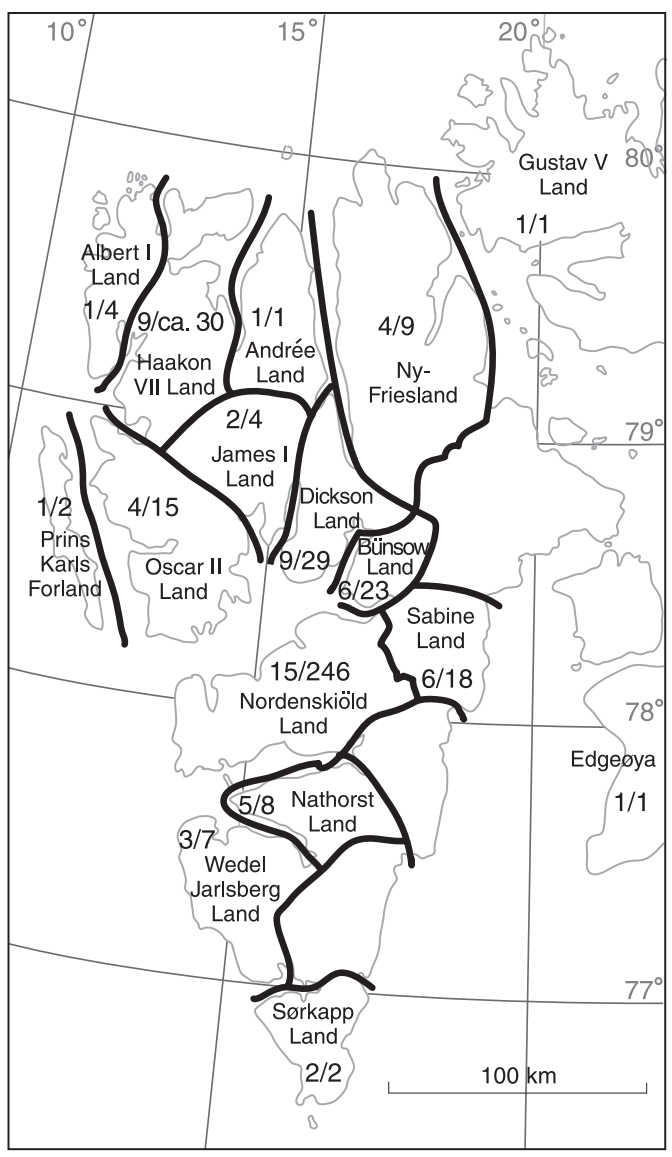

Fig. 3. Thermophilous species per province in Svalbard (Bjørnøya not shown), given as the number of species/total number of observed populations of all 20 target species. See Fig. 1 for vegetation zones.

\section{Distribution, population sizes, and state of conservation}

Populations of species are recorded in Appendix 1 based on field observations, botanical literature, Norwegian university herbaria and personal communications. Unpublished finds have been included. When more than one source reports the same find, only the most precise one is quoted.

Estimates of population size are based on occurrence within the local $1 \times 1 \mathrm{~km}$ square of the Universal Transverse Mercator $\left(\mathrm{UTM}_{\mathrm{ED} 50}\right)$ grid. Populations are rated as small, medium or large, as delineated in Table 1. The term "population" here also includes subpopulations belonging to the same metapopulation. Red List categories are assessed according to the World Conservation Union (IUCN 2001) at the regional scale of Svalbard. The proportions of populations protected were reviewed according to extant and recently established protected areas (Miljøverndepartementet 2003; Fig. 2).

\section{Ecology}

Air temperatures for the growing season were compiled from climatological literature and from Engelskjøn (1986, 1987, 1994). Notes are provided on mineral and/or organic substrata and hydrology of the habitats of each species. Accompanying species are enumerated; nomenclature mainly follows Elvebakk \& Hertel (1996), Elven \& Elvebakk (1996), Frisvoll \& Elvebakk (1996) and Gulden \& Torkelsen (1996).

Table 1. Definitions of phytogeographical terms and population size categories used in this paper.

\begin{tabular}{|c|c|}
\hline Term & Definition \\
\hline Boreal & The northern, wooded latitudinal zone. \\
\hline Arctic & The entire or most of the treeless zone. \\
\hline Low Arctic & $\begin{array}{l}\text { Southern portion of the Arctic, with prominent Betula nana, medium-sized Salix spp., Ledum } \\
\text { palustre, Vaccinium spp. or Empetrum spp., corresponding to Elvebakk's (1985) Low Arctic } \\
\text { Tundra Zone. }\end{array}$ \\
\hline High Arctic & Northern portion of the Arctic, i.e. all lands north of the Low Arctic. \\
\hline Barents Sea region & Svalbard, Franz Josef Land, Novaya Zemlya, Vaygach, Kolguyev and the polar Urals. \\
\hline Small population & $\begin{array}{l}\text { A closed stand less than } 15 \times 15 \mathrm{~m} \text {; alternatively, scattered individuals or ramets within only one } \\
\text { quarter of the } 1 \mathrm{~km} \text { UTM square. }\end{array}$ \\
\hline Medium population & $\begin{array}{l}\text { One or a few copious stands at least } 15 \times 15 \mathrm{~m} \text {, or scattered individuals } / \text { ramets in more than one } \\
\text { quarter of the } 1 \mathrm{~km} \text { UTM square. }\end{array}$ \\
\hline Large population & Generally distributed and/or abundant within one or more $1 \mathrm{~km}$ UTM squares. \\
\hline No data & No precise information is available on population size. \\
\hline
\end{tabular}




\section{Results}

Table 2 summarizes worldwide northern limits, number of populations in Svalbard, and tentative Red List categories. A more detailed account is provided in Appendix 1, which also specifies populations protected under the current conservation plan for Svalbard (Miljøverndepartementet 2003).

\section{State of conservation}

Red List categories are recorded in Table 2. Nine species are considered endangered or critically endangered in Svalbard; five species are vulnerable, and six species are at lower risk. According to the current protection plan, more than half of the known Svalbard populations of the following species are protected: Alchemilla glomerulans, Calamagrostis stricta, Carex marina ssp. pseudolagopina, Empetrum nigrum ssp. hermaphroditum, Hippuris vulgaris, Juncus castaneus, Luzula wahlenbergii, Ranunculus arcticus, R. wilanderi, Rhodiola rosea, and Rubus chamaemorus. Fewer than half of the populations of Euphrasia frigida, Juncus triglumis, Kobresia simpliciuscula, Ranunculus lapponicus, R. pal-

Table 2. Twenty thermophilous species in Svalbard. Population data from Appendix 1.

\begin{tabular}{|c|c|c|c|c|c|}
\hline Species & $\begin{array}{l}\text { Extant northern limit } \\
\text { in Svalbard }\end{array}$ & $\begin{array}{c}\text { Northern limit outside } \\
\text { of Svalbard }\end{array}$ & $\begin{array}{l}\text { No. of } \\
\text { popula- } \\
\text { tions }\end{array}$ & $\begin{array}{l}\% \text { of pop- } \\
\text { ulations } \\
\text { protected }\end{array}$ & $\begin{array}{l}\text { Red List category } \\
\text { at the regional } \\
\text { level (IUCN 2001) }\end{array}$ \\
\hline $\begin{array}{l}\text { Alchemilla glomerulans } \\
\text { Sam. }\end{array}$ & $74^{\circ} 31^{\prime}$ Bjørnøya & $\begin{array}{l}71^{\circ} 10^{\prime} \text { Nordkapp, mainland } \\
\text { Norway (Dahl 1934) }\end{array}$ & 1 & 100 & $\begin{array}{c}\text { Critically } \\
\text { endangered }\end{array}$ \\
\hline Betula nana $\mathrm{L}$. & $78^{\circ} 15^{\prime}$ Adventdalen & $76^{\circ}$ NE Greenland (Fredskild 1998) & 39 & 0 & Vulnerable \\
\hline $\begin{array}{l}\text { Calamagrostis stricta } \\
\text { (Timm) Koeler }\end{array}$ & $79^{\circ} 30^{\prime}$ Liefdefjorden & $\begin{array}{c}74^{\circ} 40^{\prime} \text { NE Greenland } \\
\text { (Bay 1992) }\end{array}$ & 108 & 53 & Lower risk \\
\hline Campanula rotundifolia $\mathrm{L}$. & $78^{\circ} 07^{\prime}$ Colesbukta & $75^{\circ} 50^{\prime}$ NE Greenland (Bay 1992) & 4 & 0 & Endangered \\
\hline $\begin{array}{l}\text { Carex marina Dew. ssp. } \\
\text { pseudolagopina (Sørensen) } \\
\text { Böcher }\end{array}$ & $79^{\circ} 30^{\prime}$ Liefdefjorden & $\begin{array}{l}83^{\circ} \mathrm{N} \text { Greenland } \\
\text { (Bay 1992) }\end{array}$ & 16 & 100 & Vulnerable \\
\hline $\begin{array}{l}\text { Empetrum nigrum L. ssp. } \\
\text { hermaphroditum (Hagerup) } \\
\text { Böcher }\end{array}$ & $80^{\circ} 30^{\prime}$ Nordaustlandet & $\begin{array}{l}79^{\circ} 10^{\prime} \text { NW Greenland } \\
\text { (Simmons 1909) }\end{array}$ & ca. 80 & 54 & Lower risk \\
\hline Euphrasia frigida Pugsley & $79^{\circ} 26^{\prime}$ Bockfjorden & $77^{\circ} 20^{\prime}$ NE Greenland (Bay 1992) & 7 & 28 & Endangered \\
\hline Hippuris vulgaris L. & 743ㅜㄴ Bjørnøya & $\begin{array}{l}82^{\circ} 13^{\prime} \mathrm{N} \text { Greenland } \\
\text { (Fredskild 1966) }\end{array}$ & 22 & 100 & Lower risk \\
\hline Juncus castaneus $\mathrm{Sm}$. & $78^{\circ} 28^{\prime}$ Gipsdalen & $83^{\circ} \mathrm{N}$ Greenland (Bay 1992) & 5 & 60 & Endangered \\
\hline Juncus triglumis L. & $79^{\circ} 30^{\prime}$ Wijdefjorden & $83^{\circ} \mathrm{N}$ Greenland (Bay 1992) & 39 & 41 & Lower risk \\
\hline $\begin{array}{l}\text { Kobresia simpliciuscula } \\
\text { (Wahlenb.) Mack. }\end{array}$ & $78^{\circ} 56^{\prime}$ Kongsfjorden & $\begin{array}{l}82^{\circ} 01^{\prime} \text { N Greenland } \\
\text { (Holmen 1957) }\end{array}$ & 8 & 38 & Endangered \\
\hline Luzula wahlenbergii Rupr. & $78^{\circ} 17^{\prime}$ Adventfjorden & $75^{\circ} 55^{\prime}$ NE Greenland (Bay 1992) & 14 & 50 & Vulnerable \\
\hline Ranunculus arcticus $\mathrm{R}$. Br. & $79^{\circ} 15^{\prime}$ Krossfjorden & $83^{\circ} \mathrm{N}$ Greenland (Bay 1992) & 25 & 84 & Vulnerable \\
\hline Ranunculus lapponicus L. & $79^{\circ}$ Wijdefjorden & $73^{\circ}$ Novaya Zemlya (Lynge 1924) & 70 & 41 & Lower risk \\
\hline $\begin{array}{l}\text { Ranunculus pallasii } \\
\text { Schlecht. }\end{array}$ & $78^{\circ} 25^{\prime}$ Bohemanflya & $\begin{array}{c}73^{\circ} \text { Novaya Zemlya } \\
\text { (Lynge 1924) }\end{array}$ & 11 & 45 & Vulnerable \\
\hline $\begin{array}{l}\text { Raunculus wilanderi } \\
\text { (Nath.) Á. \& D. Löve }\end{array}$ & $78^{\circ} 27^{\prime}$ Kapp Thordsen & $\begin{array}{l}73^{\circ} \text { Novaya Zemlya } \\
\text { (Lynge } 1924-\text { sp.?) }\end{array}$ & 1 & 100 & $\begin{array}{l}\text { Critically } \\
\text { endangered }\end{array}$ \\
\hline Rhodiola rosea $\mathrm{L}$. & $\begin{array}{l}78^{\circ} 45^{\prime} \text { Prins Karls } \\
\text { Forland }\end{array}$ & $\begin{array}{c}75^{\circ} 05^{\prime} \text { NE Greenland } \\
\text { (Bay 1992) }\end{array}$ & 30 & 100 & Lower risk \\
\hline Rubus chamaemorus L. & $78^{\circ} 38^{\prime}$ Ekmanfjellet & $73^{\circ}$ Novaya Zemlya (Lynge 1924) & 9 & 67 & Endangered \\
\hline Salix lanata L. & $78^{\circ} 12^{\prime}$ Adventdalen & $\begin{array}{c}75^{\circ} \text { Taymyr } \\
\text { (Tolmachev et al. 1996) }\end{array}$ & 2 & 0 & $\begin{array}{c}\text { Extirpated } \\
\text { (Kongsfjorden); } \\
\text { critically } \\
\text { endangered } \\
\text { (Adventdalen) }\end{array}$ \\
\hline Vaccinium uliginosum L. & 78³9' Mimerdalen & $\begin{array}{c}81^{\circ} 55^{\prime} \text { N Greenland } \\
\text { (Holmen 1957) }\end{array}$ & 5 & 20 & $\begin{array}{l}\text { Critically } \\
\text { endangered }\end{array}$ \\
\hline
\end{tabular}


lasii, and Vaccinium uliginosum are protected. None of the populations of Betula nana or Campanula rotundifolia, nor the only intact population of Salix lanata, are protected.

\section{Impact of climate}

Air temperatures and heat sums for July-August and June-September are summarized for Boreal or Arctic stations in northern Norway and Svalbard (Table 3). The island of Hopen has a comparably cold climate, summer temperatures reaching only a few degrees above zero. The climate at the southern end of Spitsbergen, represented by Hornsund, is comparable to Isfjord Radio and Bjørnøya. There is a sizeable difference in summer temperature between the coastal station Isfjord Radio, on the margin of the Middle Arctic Tundra Zone, and the Longyearbyen station in the Inner Arctic Fjord Zone (Fig. 1): degree-days (sum of mean diurnal temperatures) for JulyAugust amount to 290 and 365, respectively. The thermophilous species in Svalbard generally require a heat sum exceeding 300 degree-days for July and August. The occurrence of these species in various parts of Spitsbergen is illustrated in Fig. 3.

\section{Edaphic requirements}

Based on observations in the field, preferences of soil and hydrology are outlined for the 20 target species (Table 4). There is a considerable variation along the gradients eutrophic-oligotrophic and drained - wet.

\section{Review of species}

Thirteen thermophilous species advance farther north in Svalbard than in other Arctic lands (Table 2). Seven species occurring in Svalbard reach their northern limits in Greenland: Carex marina ssp. pseudolagopina, Hippuris vulgaris, Juncus castaneus, J. triglumis, Kobresia simpliciuscula, Ranunculus arcticus and Vaccinium uliginosum. The following 20 target species are treated in some detail with regard to their distribution

Table 3. Temperatures $\left({ }^{\circ} \mathrm{C}\right)$ and heat sums for the summer in Svalbard. Standard normals 1931-1960, if not otherwise stated. Data from Steffensen (1982) and Baranowski (1975). See also Aune (1993) for standard normals 1961-1990. Data for Tromsø and Vardø, northern Norway, included for comparison.

\begin{tabular}{|c|c|c|c|c|c|c|c|}
\hline & \multirow{2}{*}{ Northern latitude } & \multicolumn{4}{|c|}{ Mean temperature $\left({ }^{\circ} \mathrm{C}\right)$} & \multicolumn{2}{|c|}{ Degree-days } \\
\hline & & Jun. & Jul. & Aug. & Sept. & Jul.-Aug. & Jun.-Sept. \\
\hline Troms $\varnothing$ & $69^{\circ} 39^{\prime}$ & 9.4 & 12.6 & 11.5 & 7.7 & 747 & 1260 \\
\hline Vardø & $70^{\circ} 22^{\prime}$ & 6.3 & 9.3 & 9.8 & 6.8 & 590 & 983 \\
\hline Bjørnøya & $74^{\circ} 31^{\prime}$ & 2.0 & 4.5 & 5.0 & 3.0 & 295 & 445 \\
\hline Hopen (1946-1965) & $76^{\circ} 30^{\prime}$ & -0.4 & 2.0 & 2.2 & 0.9 & 130 & 157 \\
\hline Hornsund (1970-74) & $76^{\circ} 50^{\prime}$ & 2.2 & 5.3 & 4.8 & 1.7 & 315 & 432 \\
\hline Isfjord Radio & $78^{\circ} 06^{\prime}$ & 1.8 & 4.9 & 4.4 & 1.3 & 290 & 383 \\
\hline Longyearbyen & $78^{\circ} 12^{\prime}$ & 2.9 & 6.5 & 5.3 & 1.0 & 365 & 482 \\
\hline
\end{tabular}

Table 4. Twenty thermophilous vascular plant species in Svalbard according to edaphic gradients.

\begin{tabular}{|c|c|c|c|}
\hline & Drained & Moist & Wet \\
\hline Calcareous (eutrophic) & (none) & $\begin{array}{l}\text { Alchemilla glomerulans } \\
\text { Kobresia simpliciuscula }\end{array}$ & $\begin{array}{l}\text { Carex marina ssp. } \\
\text { pseudolagopina } \\
\text { Juncus castaneus } \\
\text { Juncus triglumis }\end{array}$ \\
\hline $\begin{array}{l}\text { Mixed or intermediate } \\
\text { (mesotrophic) }\end{array}$ & $\begin{array}{c}\text { Betula nana } \\
\text { Campanula rotundifolia } \\
\text { Ranunculus arcticus } \\
\text { Rhodiola rosea } \\
\text { Vaccinium uliginosum }\end{array}$ & $\begin{array}{c}\text { Euphrasia frigida } \\
\text { Ranunculus wilanderi } \\
\text { Salix lanata }\end{array}$ & $\begin{array}{l}\text { Calamagrostis stricta } \\
\text { Hippuris vulgaris } \\
\text { Ranunculus lapponicus } \\
\text { Ranunculus pallasii }\end{array}$ \\
\hline $\begin{array}{l}\text { Siliceous or humic } \\
\text { (oligotrophic) }\end{array}$ & $\begin{array}{l}\text { Empetrum nigrum ssp. } \\
\text { hermaphroditum }\end{array}$ & $\begin{array}{l}\text { Rubus chamaemorus } \\
\text { Luzula wahlenbergii }\end{array}$ & (none) \\
\hline
\end{tabular}


and ecology in Svalbard (Table 2; Appendix 1).

\section{Alchemilla glomerulans}

The species occurs at one locality on Bjørnøya (Engelskjøn 1987: 103-104), which is also its northern limit. The nearest occurrences are on Jan Mayen (Lid 1964: 54) and at Nordkapp (North Cape) (Dahl 1934: 357).

In 1983 three individuals (clones) were found in a sheltered gully on the northern coast of Bjørnøya with the bryophytes Brachythecium reflexum, Dichodontium pellucidum, Philonotis tomentella, Sanionia uncinata, Syntrichia ruralis and Timmia austriaca and the vascular species Cerastium arcticum, C. cerastoides, Festuca rubra ssp. arctica, Oxyria digyna, Ranunculus pygmaeus and Saxifraga cernua. Growing at a slightly disturbed site in the vicinity of the Bjørnøya meteorological station, A. glomerulans might have been introduced accidentally there. However, the species occurs in natural vegetation and may be native to Bjørnøya.

See the distribution map in Engelskjøn (1987: 126).

\section{Betula nana}

The species is confined to south of Isfjorden (Nathorst 1871: 113; Andersson 1910: 411; Resvoll-Holmsen 1913: 26, 53). At Colesdalen it occurs up to $210 \mathrm{~m}$ asl (Alsos, Lund et al. 2002); at Adventdalen, to $140 \mathrm{~m}$ asl (Engelskjøn, unpubl. data). Only seven among 39 populations were rated as large. Seed reproduction has not been observed in germination experiments (Misund 1997) or seed bank studies (Alsos et al. 2003; Cooper et al. in press).

Betula nana occupies depressions on welldrained, south-facing hillsides. It is associated with Cassiope tetragona and Dryas octopetala (Table 14 in Lid 1967) and in places also with Empetrum nigrum ssp. hermaphroditum or Hierochloë alpina (Engelskjøn \& Spjelkavik 1999). The mushroom, Leccinum rotundifoliae (Fig. 3 in Engelskjøn \& Spjelkavik 1999), forms mycorrhiza with dwarf birch (Gulden \& Torkelsen 1996: 190) and appears as an indicator of Low Arctic vegetation.

This is a polymorphic species, which seems to comprise several subspecific taxa (Hultén \& Fries 1986), and probably includes the northern B. tundrarum Perfilyev (Tolmachev 1976). De Groot et al. (1997: 253) summarized some taxonomic proposals on B. nana.

See distribution maps in Engelskjøn (Fig. 5 in 1986) and Elvebakk (Fig. 27 in 1989). See local maps in Hadač (Fig. 10 in 1944), Engelskjøn \& Spjelkavik (Fig. 1 in 1999) and Alsos, Lund et al. (2002).

\section{Calamagrostis stricta}

On Bjørnøya this grass is often sterile but may develop culms up to $15 \mathrm{~cm}$ tall in late August. On Spitsbergen C. stricta is characteristic of riverbanks with culms up to $27 \mathrm{~cm}$ in early August. It is rare in the calcareous valley of Sassendalen and absent on the alkaline soils of Eskerdalen (Engelskjøn, unpubl. data) and Gipsdalen (Elven et al. 1990). Twelve large populations were recorded in the Inner Arctic Fjord Zone; otherwise the rather numerous populations are medium-sized (32) or small (21).

On Bjørnøya C. stricta associates, for example, with Dupontia psilosantha, Equisetum arvense, Festuca rubra, Poa pratensis ssp. alpigena and, rarely, with Cardamine pratensis ssp. polemonioides, Carex subspathacea, Equisetum variegatum or Saxifraga cernua. On Spitsbergen the species inhabits mesotrophic to eutrophic mires, associating with Cardamine pratensis ssp. polemonioides, Colpodium vahlianum, Dupontia spp. and Eriophorum scheuchzeri.

Most Svalbard specimens resemble C. holmii Lange with short, dark panicles (see Hultén 1968: 107, 1973: 465).

See distribution maps in Rønning (map 18 in 1972), Elvebakk (Fig. 64 in 1989). See local maps in Hadač (Fig. 36 in 1944) and Engelskjøn (1987: $115)$.

Table 5. Abbreviations of herbaria mentioned in this paper, in accordance with Holmgren et al. (1990). Some of the institutional names have been updated.

\begin{tabular}{ll}
\hline BG & Botanical Institute, University of Bergen, Norway \\
C & $\begin{array}{l}\text { Botanical Museum, University of Copenhagen, } \\
\text { Denmark }\end{array}$ \\
CGE & $\begin{array}{l}\text { Botany School, University of Cambridge, UK } \\
\text { O }\end{array}$ \\
TRH & $\begin{array}{l}\text { Botanical Museum, University of Oslo, Norway } \\
\text { Nept of Bony, University of Trondheim (NTNU), }\end{array}$ \\
TROM & $\begin{array}{l}\text { Dept. of Botany, Tromsø University Museum, } \\
\text { Norway }\end{array}$ \\
\hline
\end{tabular}




\section{Campanula rotundifolia}

The species is confined to Colesbukta and Colesdalen, Spitsbergen. It was discovered in 1915 (Asplund 1919: 36) and flowering started on 13 August that year (specimens in Herbarium $\mathrm{O}$; see Table 5). This is probably the population of $C$. rotundifolia located on a hill facing Colesbukta, extending over $104 \mathrm{~m}^{2}$. Flowering started on 15 July in the exceptionally warm summer of 1998, in mid-August 1999 and at the end of July 2002. Two additional, small populations were found on the northern side of Colesdalen, succeeded towards the interior by a nearly continuous, large population extending over approximately $2600 \times 400 \mathrm{~m}$. No germinable seeds or seed bank have been observed (Alsos et al. 2003; Cooper et al. in press).

Campanula rotundifolia grows on sandstone lithosol with rock gaps and some turf with mesotrophic species such as Betula nana, Draba daurica, Dryas octopetala, Poa glauca and Polemonium boreale as well as the ubiquitous Bistorta vivipara, Luzula arcuata ssp. confusa and Salix polaris. We noted the scarcity of calciphilous species such as Carex rupestris and Saxifraga oppositifolia, which may be explained by the low amounts of calcium carbonate in the bedrock (Major \& Nagy 1966). The occurrence of Trisetum spicatum suggests some protection by relatively late-lying snow.

Situated 0.4 to $4 \mathrm{~km}$ away from the former Colesbukta mining settlement, the occurrences of $C$. rotundifolia have remained intact up to the present and are still nearly undisturbed by human activity.

Flovik (1940) found that Colesbukta plants are diploid $(2 \mathrm{n}=34)$. Diploid $C$. rotundifolia may be given the rank of subspecies or species $C$. giesekiana Vest (Böcher 1960; Gadella 1964; Laane 1968; Croff 1978; Shetler 1982).

See distribution map in Alsos, Lund et al. (2002).

\section{Carex marina ssp. pseudolagopina}

First found in Sassendalen (by Nathorst in 1882; Herbarium C), but misinterpreted as Carex lagopina $(=C$. lachenalii), this taxon was rediscovered on Spitsbergen 80 years later (Schweitzer 1966: 147 and his Fig. 2) and then referred to the synonymic $C$. amblyorhyncha V. Krecz. in accordance with Böcher (1952; see Halliday \&
Chater 1969).

Carex marina ssp. pseudolagopina is frequent at mires and ponds in Sassendalen and Gipsdalen, 3-50 $\mathrm{m}$ asl, whereas stations in Dickson Land and at Liefdefjorden are few. Occurrences apparently depend on calcareous substrata with sufficient moisture.

The species Carex marina associates with Cinclidium arcticum, Meesia uliginosa, Orthothecium chryseon, Scorpidium cossonii, Tomentypnum nitens, Cardamine pratensis ssp. polemonioides, Carex maritima, C. parallela, C. saxatilis, $C$. subspathacea, Equisetum arvense ssp. boreale, E. variegatum, Eriophorum triste, Eutrema edwardsii and Juncus triglumis. Böcher (1952: 30) pointed out the slightly halophilous and calciphilous character of C. marina (as C. amblyorhyncha) in Greenland.

See distribution maps in Böcher (Fig. 12 in 1952), Rønning (map 25 in 1972), Engelskjøn (Fig. 6 in 1986) and Elvebakk (Fig. 67 in 1989).

\section{Empetrum nigrum ssp. hermaphroditum}

Discovered at Grønfjorden (Fries 1869; cf. Elvebakk \& Spjelkavik 1995: 544), Empetrum is frequent at Isfjorden (Engelskjøn \& Spjelkavik 1999), less so at Bellsund and Van Mijenfjorden (Engelskjøn et al. 1972). It is frequent in Dickson Land (Högbom 1913; Möller \& Thannheiser 1997), inner Kongsfjorden and Liefdefjorden, but is rare in northern Svalbard (Elvebakk \& Spjelkavik 1995; Möller 2000), including Nordaustlandet, at $80.5^{\circ} \mathrm{N}$ (Brattbakk 1981 cited in Elvebakk \& Spjelkavik 1995). Empetrum ascends to approximately $200 \mathrm{~m}$ asl (Hadač 1944: 55). Only nine populations among approximately 80 are considered large.

Ripe fruits were recorded in the middle of August at Van Mijenfjorden (Holmboe 1910), on 4 September at Grønfjorden (Wirén 1922), in September at Mimerdalen (Högbom 1913: 153, his Fig. 1) and on 30 July in the warm summer of 1998. Collections from various parts of Spitsbergen bear unripe fruits that could well have reached maturity, but seed reproduction of Empetrum in Svalbard has not been observed in seed bank studies (Alsos et al. 2003; Cooper et al. in press).

Empetrum associates with Betula nana south of Isfjorden (Engelskjøn \& Spjelkavik 1999). It is acidiphilous (Elvebakk \& Spjelkavik 1995; Möller 2000) but was also observed on slightly calcifer- 
ous substrata: at Berzeliusdalen with Dryas octopetala in a carpet of Racomitrium canescens coll. and at lower Reindalen with Cassiope tetragona, Dryas octopetala, Hierochloë alpina and sparse Carex rupestris. In the middle part of Reindalen Empetrum occurs on peaty banks with Sphagnum aongstroemii, Tomentypnum nitens, Cassiope tetragona and Salix polaris.

Svalbard plants are tetraploid with $2 n=52$ (Flovik 1940; Engelskjøn 1979) and monoecious. E. hermaphroditum Hagerup, which is invariably tetraploid and has a northern distribution, was treated as a species (Fredskild 1998) or as a subspecies (Hultén 1968; Böcher et al. 1978).

See distribution maps in Elvebakk (Fig. 67 in 1989) and Elvebakk \& Spjelkavik (Fig. 2 in 1995). See local maps in Hadač (Fig. 11 in 1944) and Elvebakk \& Spjelkavik (Figs. 4, 5 in 1995).

\section{Euphrasia frigida}

This annual plant was discovered at Bockfjorden by Skifte (1960, TROM, see Rønning 1961; Elvebakk \& Spjelkavik 1981). In 1998 E. frigida was found some $150 \mathrm{~km}$ farther south, in Colesdalen (Alsos \& Lund 1999), and in 2003 a $1 \times 2 \mathrm{~m}$ patch was found at Ossian Sarsfjellet, Kongsfjorden (TROM). The nearest occurrences are at $71^{\circ} \mathrm{N}$ on Jan Mayen (Lid 1964: 60) and at Nordkapp (Dahl 1934: 382).

Detailed flora studies in Colesdalen in 2002 revealed small patches and scattered individuals of E. frigida within nine $100 \times 100$ m squares. Three habitats were located north of the settlement at Colesbukta, the remaining ones in the south-facing, northern valley slope approximately $2 \mathrm{~km}$ landward. The largest stand observed was $10 \times 70 \mathrm{~m}$, but most were a few square metres (Alsos, Lund et al. 2002).

Rønning (1961: 11) reported Euphrasia "in the hollows near the hot springs where the soil temperature is high". At Colesbukta and in Colesdalen E. frigida grows in Salix polaris communities; in Colesdalen it also grows with Bistorta vivipara, Festuca rubra ssp. arctica and Trisetum spicatum, indicating eutrophic and snow-protected conditions (Fig. 1 in Alsos \& Lund 1999). There is no geothermal heat at the Kongsfjorden and Colesbukta sites.

See distribution map in Elvebakk (Fig. 11 in 1989). See local map in Alsos, Lund et al. (2002).

Engelskjøn et al. 2003: Polar Research 22(2), 317-339

\section{Hippuris vulgaris}

This aquatic species is confined to shallow pools on Bjørnøya (Engelskjøn 1987). The northernmost station of $H$. vulgaris is in north Greenland, 82 ${ }^{\circ} 13^{\prime}$ (map no. 150 in Bay 1992), whereas the stations closest to Bjørnøya are Nordkapp

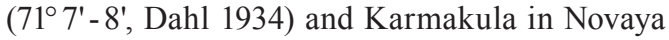
Zemlya (72²4' N, Lynge 1924: 129). Two Bjørnøya populations are rated as large; elsewhere they are medium-sized or small.

Hippuris grows in carpets of Straminergon stramineum or Warnstorfia tundrae, accompanied by Cardamine pratensis ssp. polemonioides, Dupontia psilosantha, Equisetum arvense ssp. boreale, Ranunculus hyperboreus and Saxifraga rivularis.

See the distribution map in Engelskjøn (1987: 127).

\section{Juncus castaneus}

The northernmost representatives are located in north Greenland (Fredskild 1966; Bay 1992).

On Spitsbergen J. castaneus is restricted to Gipsdalen, Sassendalen and a few places south of Isfjorden. The drawing in Rønning (Fig. 39b in 1996) is not representative since the selected culm carries only undeveloped (aborted?) capsules.

The stand at Gipsdalen is very local (Eriksen Norberg, pers. comm. 1999), growing on calcareous mud with Scorpidium cossonii. According to Schweitzer (1966: 147), J. castaneus associates with Ranunculus $\times$ spetsbergensis at De Geerdalen. One collection from Longyeardalen consisted of 12 culms with half-ripe capsules as of 6 August 1924. To our knowledge this locality has not been seen recently and the plants may have been extirpated.

See distribution maps in Rønning (map 11 in 1972) and Elvebakk (Fig. 17 in 1989).

\section{Juncus triglumis}

The species occurs in one place at Recherchefjorden and more frequently around Isfjorden, Kongsfjorden and Wijdefjorden, inhabiting calcareous fens from 5 to $70 \mathrm{~m}$ asl and associating with Cinclidium sp., Loeskypnum badium, Orthothecium chryseon, Paludella squarrosa, Scorpidium cossonii, S. turgescens, Carex marina ssp. pseudolagopina, C. parallela, C. saxatilis, 
Eutrema edwardsii and (rarely) Kobresia simpliciuscula.

The variety albescens Lange has been identified from Svalbard. It is regarded as a subspecies by some authors (Elvebakk 1989; Elven 1994; Elven \& Elvebakk 1996; Rønning 1996). Others found the varieties of J. triglumis vaguely circumscribed (Sørensen 1933: 159-161; Jørgensen et al. 1958: 47-48). The geographical ranges of ssp. triglumis and ssp. albescens are overlapping according to Hultén \& Fries (1986).

See distribution maps in Rønning (map 10 in 1972) and Elvebakk (Fig. 18 in 1989). See local map in Hadač (Fig. 36 in 1944).

\section{Kobresia simpliciuscula}

Two stations were reported at the inner branches of Isfjorden: Mimerdalen, $2 \mathrm{~km}$ from the sea (Lid 1925: 316) and Gipsdalen, 10-20 m asl (Engelskjøn 1986) as well as one at Kongsfjorden, 50-130 m asl (Elvebakk 1993). With approximately 10 tufts, the Gipsdalen population is small. The population at Mimerdalen needs investigation, whereas at least one of the populations at Kongsfjorden (Elvebakk 1993) appears as medium-sized (Elvebakk 1993: 251, 253; specimens in TROM).

At Mimerdalen K. simpliciuscula occurred with Carex parallela and Juncus triglumis (Lid 1925), and the specimens are admixed with Scorpidium cossonii, an indicator of calcareous substratum (Elvebakk 1993: 250; Frisvoll \& Elvebakk 1996: 114). At Gipsdalen $K$. simpliciuscula grew on calcareous mud accompanied by Orthothecium chryseon, Scorpidium cossonii, Bistorta vivipara, Carex marina ssp. pseudolagopina, Carex parallela, C. saxatilis, Eutrema edwardsii, Juncus biglumis, J. triglumis, the ubiquitous Salix polaris and some Draba oxycarpa, Dryas octopetala and Saxifraga hirculus.

At Kongsfjorden Kobresia occurred on calcareous substrata, as indicated by the admixed Ditrichum flexicaule, Hypnum bambergeri, Scorpidium turgescens, Tomentypnum nitens, Juncus triglumis and Tofieldia pusilla. The fens with $K$. simpliciuscula were "dominated by Carex saxatilis" (Elvebakk, note on herbarium label).

In 2001 and 2002 four small populations of Kobresia simpliciuscula were discovered in Adolfbukta (in Bünsow Land) and at Wijdefjorden (Ny-Friesland) (Elvebakk, pers. comm. 2002). Details on these localities will be given by
Elvebakk et al. (in prep.).

See distribution maps in Rønning (map 18 in 1972), Engelskjøn (Fig. 7 in 1986) and Elvebakk (1993).

\section{Luzula wahlenbergii}

The first find in Svalbard was at Bjørndalen (Nathorst 1883: 37) and subsequent finds are all from the siliceous parts of Nordenskiöld Land and Nathorst Land, not above $50 \mathrm{~m}$ asl. Only one among 14 populations may be rated as mediumsized; otherwise they are small.

Luzula wahlenbergii associates with Oncophorus wahlenbergii, Sphagnum aongstroemii, S. teres, Straminergon stramineum, Warnstorfia sarmentosa, Calamagrostis stricta, Petasites frigidus and Ranunculus pallasii. Tundra mires structured by bryophytes are vulnerable to roadbuilding and terrain wear, for instance at Reindalen (Spjelkavik 1991). Although being threatened by local road construction, $L$. wahlenbergii was found within the Longyearbyen settlement as late as 1996 (Brosø, pers. comm. 1997).

See distribution maps in Rønning (map 13 in 1972) and Elvebakk (Fig. 30 in 1989).

\section{Ranunculus arcticus}

Ranunculus arcticus is dispersed in Svalbard from Edgeøya (Neilson 1970: 35, as R. pedatifidus) and Sørkapp (South Cape) northwards to Krossfjorden. It occupies sunny promontories to $230 \mathrm{~m}$ asl at Sassenfjorden (Elvebakk \& Hodin 1985, TROM).

Neilson (1970) found the species co-dominant at a bird rookery on Edgeøya, but we believe most $R$. arcticus populations are small. A characteristic inhabitant of south-exposed hills with $F$. rubra ssp. arctica, $R$. arcticus associates with less common species such as Draba arctica, D. norvegica, Festuca baffinensis, Polemonium boreale, Potentilla hyparctica, P. ×insularis, Silene furcata, Taraxacum arcticum and $T$. brachyceras.

Simmons (1906: 101-108) and Lynge (1924: 35 and pl. XXI) discuss the nomenclature of $R$. affinis/R. arcticus (see Ericsson 2001: 256). The related $R$. pedatifidus Sm., to which the Svalbard plants were referred in earlier treatments, originates from the mid-latitude Altay Mountains (Hadač 1944).

See the distribution map in Elvebakk (Fig. 53 in

Twenty thermophilous vascular plant species in Svalbard 

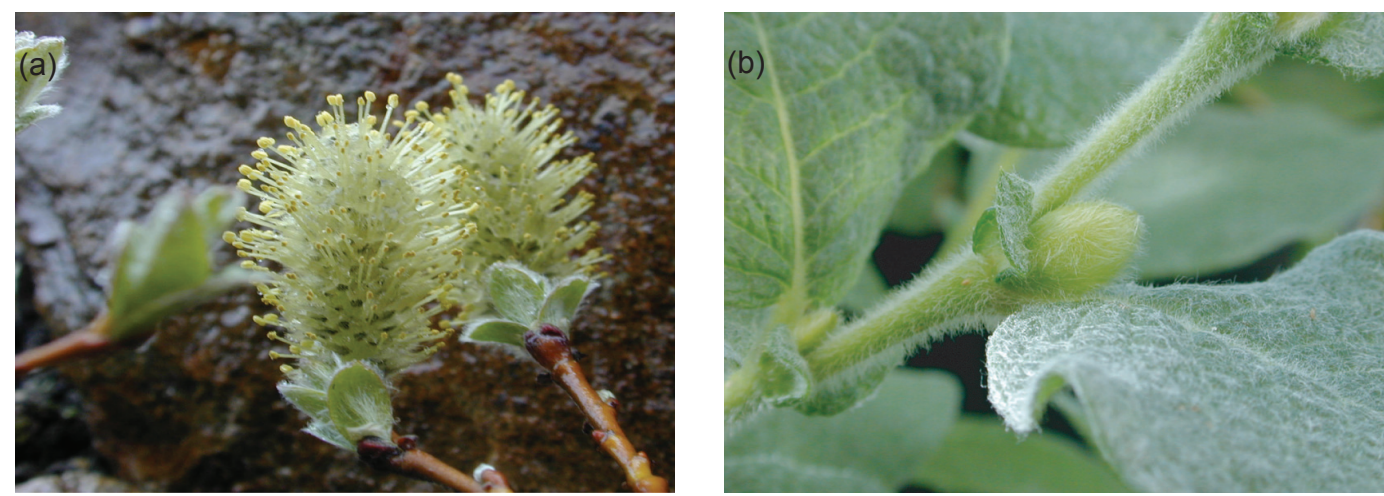

Fig. 4. Salix lanata from Adventdalen, Svalbard. (a) Male individual cultivated at Tromsø Botanic Gardens. Photo: I. G. Alsos (4 May 2002). (b) Twig of cloned offspring cultivated in the phytotron (T $15^{\circ} \mathrm{C} ; 24 \mathrm{hrs}$ daylight), 1998-2002. Note the stipules. Photo: L. Lund (March 2002).

1989). See local map in Hadač (Fig. 50 in 1944).

\section{Ranunculus lapponicus}

The species extends from Bromelldalen south of Van Mijenfjorden northwards to Wijdefjorden (Nathorst 1883), from $5 \mathrm{~m}$ upwards to $130 \mathrm{~m}$ asl. A record of R. lapponicus from Edgeøya (Michelmore 1934) is not documented (see Dahl 1937: 25). Among 37 local populations of known size we consider only two as large (Appendix 1).

In Adventdalen, Colesdalen and Reindalen Ranunculus lapponicus occurs in bryophyte communities of Aulacomnium palustre, A. turgidum, Oncophorus wahlenbergii, Paludella squarrosa, Sphagnum fimbriatum, S. squarrosum, S. teres, Sanionia uncinata, Tomentypnum nitens or Warnstorfia tundrae. It associates with Carex subspathacea, Dupontia fisherii, Equisetum arvense ssp. boreale, Petasites frigidus (Table 20 in Lid 1967), Ranunculus hyperboreus, $R$. ×spetsbergensis, $R$. pallasii and Salix polaris.

See distribution maps in Engelskjøn (Fig. 8 in 1986) and Elvebakk (Fig. 52 in 1989). See local map in Hadač (Fig. 53 in 1944).

\section{Ranunculus pallasii}

The species is known from Reindalen, extending $21 \mathrm{~km}$ inland and upwards to $70 \mathrm{~m}$ asl, and from a few places at Isfjorden (Hadač 1944), reaching $100 \mathrm{~m}$ asl at interior Colesdalen (Engelskjøn \& Spjelkavik 1999). Records of $R$. pallasii prior to Nathorst (1883: 21) partly include $R$. ×spetsbergensis, and those from Hornsund (Triloff 1944:
292) and Prins Karls Forland (Brown 1908: 315) probably refer to the latter.

The rhizomes are immersed during the first half of summer. Characteristic accompanying species are Scapania sp., Sphagnum squarrosum, Warnstorfia exannulata, $W$. fluitans, $W$. sarmentosa, Ranunculus lapponicus, $R$. ×spetsbergensis and Carex subspathacea. On the Reindalsletta plain, 6 August 1985, we observed the drying out of the pools harbouring $R$. pallasii.

See distribution maps in Engelskjøn (Fig. 9 in 1986) and Elvebakk (Fig. 31 in 1989).

\section{Ranunculus wilanderi}

Restricted to a boggy plain inside Kapp Thordsen at Isfjorden, $R$. wilanderi was first observed, but not named, by Nathorst (1871). In his original description Nathorst (1883: 23-24) recorded it "in two places" at Kapp Thordsen, whereas the population was considered as "fairly extensive" by Elven \& Elvebakk (1996: 40). Plants apparently numbered not more than 20 in 1996. They were confined to runnels between a dolerite cliff with Ranunculus arcticus and a Sphagnum moor with abundant, sterile Rubus chamaemorus.

Described as $R$. affinis *Wilanderi, this is a member of the $R$. auricomus complex (Ericsson 2001: 237 and his Fig. 105b), apparently close to var. glabrata Lynge (1924: 35-36, pl. XXII). The latter was described from Novaya Zemlya, and subsequently identified from north-eastern Greenland (Sørensen 1933: 53-54). Var. glabrat $a$ was ranked as a species R. glabratus by Fagerström \& Kvist (1983). 


\section{Rhodiola rosea}

The species was first discovered in Svalbard by Keilhau (1831) on his pioneer visit to Bjørnøya. This island has most of Rhodiola in Svalbard (Engelskjøn \& Schweitzer 1970; Engelskjøn 1987). Two large populations inhabit the cliffs and promontories of the north-eastern and south-western coasts; otherwise the species is scattered with a few individuals. Occurrences on Prins Karls Forland (Brown 1908: 318), including Richardlaguna (Rønning, pers. comm. 1985), need further study. Pollen of Rhodiola has been found in droppings of incubating barnacle geese at Lovénøyane islands in Kongsfjorden (Alm \& Alsos, unpubl. data 1999), suggesting that the species also may occur in that area.

Growing near the coastal brink of Bjørnøya, Rhodiola prefers bedrock of Kulm sandstone and associates with Cochlearia groenlandica, Draba norvegica, Festuca rubra ssp. arctica, F. vivipara and Poa pratensis ssp. alpigena. There is also a Rhodiola-Luzula arcuata community.

The broad-leaved, dwarfed Svalbard strain (Fig. 9 in Engelskjøn \& Schweitzer 1970) is referable to ssp. arctica (A. Boriss.) Á. \& D. Löve (Borissova 1939: 30-31, 171-172).

See the distribution map in Elvebakk (Fig. 33 in 1989). See local map in Engelskjøn (1987: 124).

\section{Rubus chamaemorus}

Rubus chamaemorus is restricted to moors near Isfjorden. One stand at Kapp Thordsen measures at least $50 \times 50 \mathrm{~m}$ and is rated as mediumsized. Due to lack of flowers in 1996, the local proportion of pistillate/staminate plants is unknown. At Rusanovodden, near Colesbukta, south of the Rusanov hut, there were (in 1998) four stands (with staminate flowers), measuring $6 \times 9 \mathrm{~m} ; 4 \times 8 \mathrm{~m} ; 2 \times 4 \mathrm{~m}$, and $6 \times 7 \mathrm{~m}$, as well as (in 2002) two stands (with pistillate flowers), measuring $5 \times 20 \mathrm{~m}$ and $20 \times 20 \mathrm{~m}$. One stand north of the Rusanov hut, not flowering in 2002, covered approximately $100 \mathrm{~m}^{2}$. At Colesdalen, near the cemetery south-east of the former mining settlement, two patches of staminate plants were found, each $6 \times 6 \mathrm{~m}$ (Alsos, Lund et al. 2002).

Two pistillate stands below Ekmanfjellet were both approximately $10 \times 3 \mathrm{~m}$, and a staminate one at the river Hemsil was $9 \times 11.5 \mathrm{~m}$ in 1998 . At Sveasletta, west of Ekmanfjorden, one stand exceeded $10 \times 10 \mathrm{~m}$ (Wirén 1922; Hauge, pers. comm. 1998). Flowering has been observed at most localities, but seed set is weak because of the prevailing unisexual clones. Ripe fruits were recorded at Sveasletta in the warm season of 1998 (Hauge, pers. comm. 1998).

The stands at Kapp Thordsen are on peat, mainly of Sphagnum fimbriatum. At Rusanovodden Rubus chamaemorus associates with Aulacomnium turgidum, Dicranum laevidens, Polytrichum strictum, Sphagnum aongstroemii or $S$. squarrosum, Betula nana and Luzula arcuata ssp. confusa. At Colesdalen Rubus occurs in mesotrophic bryophyte carpets. The stands west of Ekmanfjorden support Cassiope tetragona and a number of lichen species, e.g. Pilophorus robustus, suggesting rather dry conditions.

See the distribution map in Elvebakk (Fig. 22 in 1989). See local map in Alsos, Lund et al. (2002).

\section{Salix lanata}

One Spitsbergen occurrence of a disputed Salix sp. is located on the northern brink of Adventelva, WSW of the Helvetia pingo (Innerhytta). It was discovered by Schweitzer in 1963 (see Hultén 1964; Schweitzer 1966). The juvenile, sparse material was first identified by Hultén as S. glauca L. ssp. callicarpaea (Trautv.) Böcher (see Hultén 1958, 1964). We have studied this occurrence in 1986, 1998 and 2001. Four small clones were permanently established over an area of $10 \times 30 \mathrm{~m}$. Only staminate catkins developed in the field and in cultivation at Tromsø Botanic Gardens (Fig. 4a).

The Adventdalen Salix grows in bryophyte carpets, mainly of Tomentypnum nitens, together with Alopecurus borealis, Calamagrostis stricta, Equisetum arvense ssp. boreale, Poa pratensis ssp. alpigena, Bistorta vivipara and Salix polaris. Patches of Dryas octopetala occurred on drier parts of the moist, sloping terrace, which is subjected to river undercutting and may become destroyed in the course of a few decades.

Elven \& Elvebakk (1996: 41) reported another medium-sized Salix (as S. arctica) from $\mathrm{Ny-}$ Ålesund. That individual was extirpated in $1990 / 1991$ according to a note on the herbarium label by O. I. Rønning. We have studied material collected in 1974 and (as a dead twig) in 1991 (TRH), and a colour photograph from 1976 (Elvebakk, pers. comm. 2002), to compare it with the Adventdalen plants. In Elvebakk's photograph 
the sterile Salix sp. is seen with Bistorta vivipara, Salix polaris and Saxifraga oppositifolia.

Propagation of a twig transplanted from the Adventdalen Salix in 1998 (Fig. 4b) did not confirm Hultén's original identification of it as $S$. glauca ssp. callicarpaea, nor as S. arctica proposed by Elven (1994), Elven \& Elvebakk (1996), Rønning (1996) and Elven \& Karlsson (2000: 141). Its identification as $S$. lanata was suggested by George Argus, leading salicologist of North America, who has examined photographs and herbarium specimens from Adventdalen (pers. comm. 2002). This is corroborated by leaf morphology and venation, well-developed stipules (Fig. 4b), pale yellowish indumentum of shortpedunculate catkins, yellow anthers and glabrous anther filaments (Fig. 4a).

Carrying obovate, reticulate leaves, the sparse material from Ny-Ålesund is also referable to Salix lanata.

Both populations resemble low-growing strains of ssp. richardsonii (Hook.) A. Skvortzov, a view advanced by Elven (pers. comm. 2002). Further investigation is needed to assess the local distribution and phytogeographical connections of Salix lanata in Spitsbergen.

\section{Vaccinium uliginosum}

The species was discovered in 1908 at Mimerdalen (Lid 1925) and subsequently collected at what was then known as Coles Bay by G. Holmsen in 1912. The Vaccinium habitat at Kreklingpasset, north of Adventdalen, approximately 200 $\mathrm{m}$ asl, was exposed to natural erosion in 1981 (J. Nilsen, pers. comm. 1999). The species was not seen there in 1998 and may have been locally extirpated.

The Colesdalen population is medium-sized, covering more than half of an area of $1360 \mathrm{~m}^{2}$ (consisting of one genotype), with two satellites (a closely related genotype) extending over $3.2 \mathrm{~m}^{2}$ and $16 \mathrm{~m}^{2}$, located $32 \mathrm{~m}$ and $40 \mathrm{~m}$ uphill, respectively (Alsos, Brochman et al. 2002). The Colesdalen habitat is a south-facing slope with prostrate Vaccinium mixed with Cassiope tetragona and Dryas octopetala. At Rusanovodden, $40 \mathrm{~m}$ asl, another medium-sized population, not flowering, was discovered in 2002. It occurred with Betula nana and Empetrum nigrum ssp. hermaphroditum (Alsos, Lund et al. 2002).

No germinable seeds or seed bank have been found in the Colesdalen population, the only place where flowers or fruits have been observed in Svalbard (Alsos et al. 2003; Cooper et al. in press).

One Vaccinium stand at Mimerdalen extending over a few square metres, probably on the hill Estheriahaugen (O. A. Høeg, 1928, TRH), was accompanied by Dryas octopetala, Carex rupestris, Bistorta vivipara, Luzula arcuata ssp. confusa, Salix polaris, Dicranum laevidens, Tomentypnum nitens and several fruticose lichens, e.g. Thamnolia vermicularis (Möller \& Thannheiser 1997).

Idodalen harbours stands of two partly overlapping $V$. uliginosum genotypes measuring $120 \mathrm{~m}^{2}$ and $60 \mathrm{~m}^{2}$, only $3 \mathrm{~m}$ apart (Alsos, Brochman et al. 2002). Co-dominant were Cassiope tetragona, Saxifraga oppositifolia and Tomentypnum nitens associating with some restricted, calciphilous species, e.g. Tofieldia pusilla.

Material from Colesbukta was found to be diploid with $2 n=24$ (Flovik 1940). All the Svalbard populations are referred to the circumpolar ssp. microphyllum (Lge.) Tolm. (Alsos et al. 2003).

See the distribution map in Elvebakk (Fig. 32 in 1989). See local map in Alsos, Lund et al. (2002.)

\section{Discussion}

The Spitsbergen ranges of the thermophilous species broadly coincide with the Inner Arctic Fjord Zone (Elvebakk 1989), where the Longyearbyen meteorological station enjoys the highest summer warmth, 365 degree-days for July-August. However, we consider this local climate as marginal for the following 12 target species which require more than 400 degree-days for July-August (data from Engelskjøn 1994): Alchemilla glomerulans, Betula nana, Calamagrostis stricta, Campanula rotundifolia, Euphrasia frigida, Hippuris vulgaris, Juncus castaneus, J. triglumis, Ranunculus lapponicus, Rubus chamaemorus, Salix lanata and Vaccinium uliginosum. Lack of viable seeds or seed bank in three of these species, i.e. $B$. nana, $C$. rotundifolia and $V$. uliginosum, suggests that thermal requirements for seed production have not been met during recent decades (Misund 1997; Alsos et al. 2003).

Among the 20 thermophilous species treated here, 13 attain their northernmost limits in Svalbard. The remaining seven have their polar limits 
in northern Greenland, from $81^{\circ} 55^{\prime}$ to $83^{\circ} \mathrm{N}$ (Fredskild 1966; Bay 1992, 1997). A farthest north station of "Empetrum nigrum" (Edlund \& Alt 1989) indicates that Ellesmere Island also possesses world northern limits of flora.

Other Boreal or Arctic species have been recorded in the fossil or subfossil state north of their present ranges. Instances are Angelica cf. archangelica (Bjørnøya, Wohlfahrt et al. 1995); Armeria scabra (Edgeøya, Bennike \& Hedenäs 1995); Parnassia palustris (Spitsbergen, van der Knaap 1988); Saussurea alpina (Spitsbergen, van der Knaap 1988) and Selaginella selaginoides (Jan Mayen, van der Knaap 1987). Possible relict occurrences of these or other warmth-demanding species should be searched for in the Inner Arctic Fjord Zone of Svalbard.

Eutrophic, mesotrophic and oligotrophic species are represented in the group of thermophilous species. There is no over-representation of species with particular edaphical demands (see Elvebakk 1982).

The following three species have most populations: Calamagrostis stricta (108), Empetrum nigrum ssp. hermaphroditum (approximately 80), and Ranunculus lapponicus (70). In these cases, medium-sized or large populations prevail and the species may be locally copious. Accordingly, they were rated as at lower risk in Svalbard.

Less frequent, with 22 to 39 populations, are Betula nana, Hippuris vulgaris (found only on Bjørnøya), Juncus triglumis, Rhodiola rosea (mainly on Bjørnøya) and Ranunculus arcticus. They are rated as vulnerable or at lower risk.

Species with 1-16 populations are Alchemilla glomerulans (only on Bjørnøya), Campanula rotundifolia, Carex marina ssp. pseudolagopina, Euphrasia frigida, Juncus castaneus, Kobresia simpliciuscula, Luzula wahlenbergii, Ranunculus pallasii, R. wilanderi, Rubus chamaemorus, Salix lanata and Vaccinium uliginosum. Depending on local conditions, they are rated as vulnerable, endangered or critically endangered.

The latter category-critically endangered at the regional level-comprises Alchemilla glomerulans (confined to Bjørnøya), Ranunculus wilanderi (confined to Kapp Thordsen), Salix lanata (extirpated at Ny-Ålesund, persisting at Adventdalen) and Vaccinium uliginosum (critically endangered at Colesdalen because of a mining scheme).

Among the target species, Betula nana, Campanula rotundifolia and Salix lanata are entire-

ly unprotected by the present area-based conservation plan (Fig. 2). One Svalbard population of Salix lanata has probably become extirpated, the remaining one, consisting of only male plants, is threatened by natural erosion. Ex situ conservation is now being implemented at the Phytotron of the University of Tromsø and Tromsø Botanic Gardens.

There are strong Norwegian and Russian mining interests within several of the proposed nature reserves in Svalbard. As a result, the Norwegian conservation authorities have signalled that mining and conservation interests should be combined to some extent within the protected areas (Miljøverndepartementet 2003). The proposed protected area at Colesdalen (Governor of Svalbard 1999; Alsos, Lund et al. 2002) has been disputed due to Russian mining interests and has so far not been protected by the Norwegian government (Miljøverndepartementet 2003), contrary to botanical recommendations. This area includes populations of Betula nana, Campanula rotundifolia, Empetrum nigrum ssp. hermaphroditum, Euphrasia frigida, Ranunculus lapponicus and Vaccinium uliginosum.

The climate-correlated, northward decline of vascular plant species (Murray 1997) shows a local anomaly in the Inner Arctic Fjord Zone of Spitsbergen, especially in Dickson Land, Sabine Land and Nordenskiöld Land, which altogether harbour more than 15 thermophilous species (Fig. 3). Due to its small and fragmented populations, this phytogeographical element needs further investigation as to its Holocene past. It is clearly in need of conservation.

\footnotetext{
Acknowledgements.-We thank Liv Borgen, Arne Pedersen, Hans-Joachim Schweitzer and associates for participating in fieldwork in 1967, 1970 or both; Sigbjørn Dunfjeld and Ola Skifte in 1983; Christian Brochmann, Arve Elvebakk, Reidar Elven, Lars Hodin and Sigmund Spjelkavik in 1985; Jan Thomas Schwenke, Sigmund Spjelkavik and Anne Steilnes in 1986; Knut Engelskjøn and Anne Steilnes in 1987; Mari Aasen in 1998, Bjørn Erik Sandbakk in 1998, 1999, 2002 and 2003, members of the North Norwegian Botanical Association in 2002 and Kjell Tore Hansen in 2003. Geir Mathiassen provided notes on Betula nana and mushrooms at Adventdalen in 1986; information on Juncus castaneus was provided by May-Britt Eriksen Norberg; on Luzula wahlenbergii by Birgit Brosø, on Rubus chamaemorus by Ivar Hauge and Jarle Nilsen and on Vaccinium uliginosum by Jarle Nilsen. We thank George Argus, Merrickville, Ontario, and Reidar Elven, Oslo, for comments on the Adventdalen Salix lanata, and Arve Elvebakk for providing an in situ photograph of the presently extirpated $S$. lanata at Ny-Ålesund. We are indebt-
} 
ed to Ernst Høgtun for preparing the maps. The present study was financed by Tromsø Museum, the Norwegian Polar Institute, the Norwegian National Committee for Polar Research (7/221.34-10/98) and the Roald Amundsen Centre for Arctic Research (A 21/98). Arve Elvebakk shared some unpublished plant finds and provided valuable comments on the manuscript, as did Torbjørn Alm. Elisabeth Cooper reviewed the language. We thank the anonymous reviewers for constructive suggestions.

\section{References}

Alsos, I. G. 2000: Utbredelse av sjeldne karplanter sett $i$ forhold til "Plan for nye verneområder på Svalbard". (Distribution of rare vascular plants in relation to the "Plan for new protected areas in Svalbard.") Polarflokken 23, 193 201.

Alsos, I. G. 2003: Conservation biology of the most thermophilous plant species in the Arctic. Genetic variation, recruitment and phytogeography in a changing climate. Dr. Scient. thesis, University of Tromsø.

Alsos, I. G., Brochmann, C. \& Engelskjøn, T. 2002: Conservation genetics and population history of Betula nana Vaccinium uliginosum, and Campanula rotundifolia in the Arctic archipelago of Svalbard. Arct. Antarct. Alp. Res. 34, 408-418.

Alsos, I. G. \& Lund, L. 1999: Fjelløyentrøst Euphrasia frigida funnet i Colesdalen, Svalbard. (Euphrasia frigida found in Colesdalen, Svalbard.) Blyttia 57, 36

Alsos, I. G., Lund, L., Sandbakk, B. E. \& Westergaard, K. 2002: Floraen $i$ Colesdalen. Kartlegging av det planlagte verneomraide. (The flora of Colesdalen. Mapping of the planned protected area.) Tromsø: Botany Unit, Troms $\varnothing$ Museum, University of Tromsø.

Alsos, I. G., Spjelkavik, S. \& Engelskjøn, T. 2003: Seed bank size and composition of Betula nana, Vaccinium uliginosum, and Campanula rotundifolia in Svalbard and northern Norway. Can. J. Bot. 81, 220-231.

Andersson, G. 1910: Die jetzige und fossile Quartärflora Spitzbergens als Zeugnis von Klimaänderungen. (The present and fossil Quaternary flora of Spitsbergen as evidence for climatic change.) In: II. internationaler Geologenkongress. Die Veränderungen des Klimas seit dem Maximum der letzten Eiszeit. Pp. 409-417. Stockholm: Generalstabens Litografiska Anstalt.

Andersson, G. \& Hesselman, H. 1900: Bidrag till kännedomen om Spetsbergens och Beeren Eilands kärlväxtflora grundade på iakttagelser under 1898 års svenska polarexpedition. (Contribution to the vascular flora of Spitsbergen and Bjørnøya based on observations during the Swedish polar expedition 1898.) Bihang Kungliga Svenska Vetenskaps-Akademiens Handlingar 26, III, 1-88.

Asplund, E. 1919: Beiträge zur kenntnis der flora des Eisfjordgebietes. (Contribution to the flora of the Isfjorden area.) Ark. Bot. 15, 1-40.

Aune, B. 1993: Temperaturnormaler, normalperiode 19611990. (Temperature normals, normal period 1961-1990.) Klima 93. Oslo: Norwegian Meteorological Institute.

Baranowski, S. 1975: The climate of west Spitsbergen in the light of material obtained from Isfjord Radio and Hornsund. Acta Univ. Wratislav. 251, 21-34.

Bay, C. 1992: A phytogeographical study of vascular plants of northern Greenland-north of $74^{\circ}$ northern latitude. Medd. Grønl. Biosci. 36.

Bay, C. 1997: Floristic and ecological characterization of the polar desert zone of Greenland. J. Veg. Sci. 8, 685-696.

Bennike, O. \& Hedenäs, L. 1995: Early Holocene land floras and faunas from Edgeøya, eastern Svalbard. Polar Res. 14, 205-214.

Birks, H. H. 1991: Holocene vegetational history and climatic changes in west Spitsbergen - plant macrofossils from Skardtjørna, an Arctic lake. The Holocene 1, 209-218.

Böcher, T. W. 1952: A study of the circumpolar Carex Heleonastes-amblyorhyncha complex. Acta Arct. 5, 1-32.

Böcher, T. W. 1960: Experimental and cytological studies on plant species $V$. The Campanula rotundifolia complex. Biol. Skr. Dan. Vidensk. Selsk. 11, 1-69.

Böcher, T. W., Holmen, K., Fredskild, B. \& Jakobsen, K. 1978: Grønlands flora. 3. reviderede udgave. (The flora of Greenland. 3rd revised edition.) Copenhagen: P. Haase \& Søn.

Borissova, A. G. 1939: Crassulaceae DC. Flora SSSR 9, 8134, 471-486.

Cooper, E. J., Alsos, I. G., Hagen, D., Smith, F. M., Coulson, S. \& Hodkinson, I. in press: Plant recruitment in the High Arctic: seed bank and seedling emergence in the field on Svalbard. J. Veg. Sci.

Croff, B. E. 1978: Campanula rotundifoliakomplekset $i$ Norge. En cytologisk og morfologisk analyse. (The Campanula rotundifolia complex in Norway. A cytological and morphological analysis.) Cand. real. thesis, University of Oslo.

Dahl, E. 1937: On the vascular plants of eastern Svalbard. Skrifter om Svalbard og Ishavet 75. Oslo: Norway's Svalbard and Arctic Ocean Research Survey (predecessor of the Norwegian Polar Institute).

Dahl, E. \& Hadač, E. 1946: Et bidrag til Spitsbergens flora. (A contribution to the flora of Spitsbergen.) Meddelelser 63. Oslo: Norway's Svalbard and Arctic Ocean Research Survey (predecessor of the Norwegian Polar Institute).

Dahl, O. 1934: Floraen i Finnmark fylke. (The flora of Finnmark county.) Nyt Magazin for Naturvidenskaberne 169.

De Groot, W. J., Thomas, P. A. \& Wein, R. W. 1997: Betula nana L. and Betula glandulosa Michx. J. Ecol. 85, 241264.

Dubiel, E. 1990: Vascular plants of the NW part of Sørkapp Land (Spitsbergen). Distribution and habitats. Zesz. Nauk. Univ. Jagiell. Prace Bot. 21, 7-33.

Edlund, S. A. \& Alt, B. T. 1989: Regional congruence of vegetation and summer climate patterns in the Queen Elizabeth Islands, Northwest Territories, Canada. Arctic 42, 3-23.

Elvebakk, A. 1982: Geological preferences among Svalbard plants. Inter-Nord 16, 11-31.

Elvebakk, A. 1985: Higher phy tosociological syntaxa on Svalbard and their use in subdivision of the Arctic. Nordic $J$ Bot. 5, 273-284.

Elvebakk, A. 1989: Biogeographical zones of Svalbard and adjacent areas based on botanical criteria. Dr. scient. thesis, University of Tromsø.

Elvebakk, A. 1993: Myrtust (Kobresia simpliciuscula) på Svalbard. (Kobresia simpliciuscula in Svalbard.) Polarflokken 17, 249-254.

Elvebakk, A., Elven, R., Spjelkavik, S., Thannheiser, D. \& Schweitzer, H.-J. 1994. Botrychium boreale and Puccinellia angustata ssp. palibinii new to Svalbard. Polarflokken 18, 133-140.

Elvebakk, A., Engelskjøn, T. \& Hodin, L. 1987: Vegetasjons-

Engelskjøn et al. 2003: Polar Research 22(2), 317-339 
skader i Berzeliusdalen. (Vegetation damage at Berzeliusdalen.) In P. Prestrud \& N. A. Øritsland (eds.): Miljøundersøkelser i tilknytning til seismisk virksomhet på Svalbard 1986. Nor. Polarinst. Rapp.ser. 34, 161-194. P. Prestrud (eds.): A catalogue of Svalbard plants, fungi, algae, and cyanobacteria. Nor. Polarinst. Skr. 198, 271359.

Elvebakk, A. \& Spjelkavik, S. 1981: Botanisering blant varme kjelder og vulkanar på Nord-Svalbard. (Botanizing among hot springs and volcanos in northern Svalbard.) Polarflokken 5, 104-113.

Elvebakk, A. \& Spjelkavik, S. 1995: The ecology and distribution of Empetrum nigrum ssp. hermaphroditum on Svalbard and Jan Mayen. Nord. J. Bot. 15, 541-552.

Elven, R. 1994 (ed.): Johannes Lid, Dagny Tande Lid: Norsk flora. (Johannes Lid, Dagny Tande Lid: Norwegian flora.) Oslo: Det Norske Samlaget.

Elven, R. \& Elvebakk, A. 1996: Vascular plants. In A. Elvebakk \& P. Prestrud (eds.): A catalogue of Svalbard plants, fungi, algae, and cyanobacteria. Nor. Polarinst. Skr. 198, 9-55.

Elven, R. \& Elvebakk, A. 2002: Sibirstarr Carex bigelowii ssp. arctisibirica på Svalbard og noe om stivstarr-komplekset $C$. bigelowii coll. (Carex bigelowii ssp. arctisibirica in Svalbard and comments on the C. bigelowii complex.) Blyttia 60, 50-58. Engelskjøn, T. 1990: Gipsdalen, central Svalbard; flora, vegetation and botanical values. In B. Brekke \& R. Hanson (eds.): Environmental atlas, Gipsdalen, Svalbard. II. Nor. Polarinst. Rapp.ser. 61, 27-66.

Elven, R. \& Karlsson, T. 2000: Salicaceae: Salix arctica Pall. In B. Jonsell (ed.): Flora Nordica 1. Lycopodiaceae-Polypodiaceae. Pp. 141-142. Stockholm: Bergius Foundation.

Engelskjøn, T. 1979: Chromosome numbers in vascular plants from Norway, including Svalbard. Opera Bot. 52, 1-38.

Engelskjøn, T. 1986: Zonality of climate and plant distribution in some Arctic and Antarctic regions. Nor. Polarinst. Rapp.ser. 30.

Engelskjøn, T. 1987: Eco-geographical relations of the Bjørnøya vascular flora, Svalbard. Polar Res. 5, 79-127.

Engelskjøn, T. 1994: High- and mid-alpine vegetation in north Scandinavia. Ecology and thermal relations. Tromura, Naturvitenskap 74. Tromsø: Tromsø Museum, Univesrity of Tromsø.

Engelskjøn, T., Kramer, K. \& Schweitzer, H.-J. 1972: Zur flora des Van Mijenfjordengebietes und Hopens. (Contribution to the flora of the Van Mijenfjorden district and Hopen.) Nor. Polarinst. Arb. 1970, 191-198.

Engelskjøn, T. \& Schweitzer, H.-J. 1970: Studies on the flora of Bear Island (Bjørnøya). I. Vascular plants. Astarte 3, 136.

Engelskjøn, T. \& Spjelkavik, S. 1999: Vegetasjon med dvergbjørk (Betula nana L.) ved Colesdalen, Svalbard. (Vegetation supporting dwarf birch (Betula nana L.) at Colesdalen, Svalbard.) Polarflokken 23, 21-28.

Ericsson, S. 2001: Ranunculaceae: Ranunculus auricomus. In B. Jonsell (ed.): Flora Nordica 2. Chenopodiaceae-Fumariaceae. Pp. 237-255. Stockholm: Bergius Foundation.

Fagerström, L. \& Kvist, G. 1983: Vier neue arktische und subarktische Ranunculus auricomus-Sippen. Ann. Bot. Fenn. 20, 237-243.

Flovik, K. 1940: Chromosome numbers and polyploidy within the flora of Spitzbergen. Hereditas 26, 430-440.
Elvebakk, A. \& Hertel, H. 1996: Lichens. In A. Elvebakk \&

Elven, R., Eriksen, M.-B., Elvebakk, A., Johansen, B. \&

Fredskild, B. 1966: Contribution to the flora of Peary Land, north Greenland. Medd. Grønl. 178(2).

Fredskild, B. 1998: The vegetation types of northeast Greenland. Medd. Grønl. Biosci. 49.

Fries, T. M. 1869: Tillägg till Spetsbergens fanerogam-flora. (Addition to the phanerogamic flora of Spitsbergen.) Öfversigt Kungliga Vetenskaps-Akademiens Förhandlingar 26, 121-144.

Frisvoll, A. A. \& Elvebakk, A. 1996: Bryophytes. In A. Elvebakk \& P. Prestrud (eds.): A catalogue of Svalbard plants, fungi, algae, and cyanobacteria. Nor. Polarinst. Skr. 198 , 57-172.

Gadella, W. 1964: Cytotaxonomical studies in the genus Campanula. Wentia 11 .

Governor of Svalbard 1999: Melding om konsekvensutredning. Plan for nye verneområder på Svalbard. (Consequence assessment report. Plan for new protected areas in Svalbard.) Longyearbyen: Office of the Governor of Svalbard.

Gulden, G. \& Torkelsen, A. E. 1996: Fungi I. Basidiomycota: Agaricales, Gasteromycetales, Aphyllophorales, Exobasidiales, Dacrymycetales and Tremellales. In A. Elvebakk \& P. Prestrud (eds.): A catalogue of Svalbard plants, fungi, algae, and cyanobacteria. Nor. Polarinst. Skr. 198, 173206

Hadač, E. 1944: Die Gefässpflanzen des "Sassengebietes" Vestspitsbergen. (The vascular plants of the "Sassen Quarter", west Spitsbergen.) Skrifter om Svalbard og Ishavet 87. Oslo: Norway's Svalbard and Arctic Ocean Research Survey (predecessor of the Norwegian Polar Institute)

Halliday, G. \& Chater, A. O. 1969: Carex marina Dewey, an earlier name for C. amblyorhyncha Krecz. Feddes Repert. 80, 103-106.

Hansen, J. R., Hansson, R. \& Norris, S. 1996: The state of the European Arctic environment. Environmental Monograph 3. Oslo: European Environment Agency.

Hjelmstad, R. 1981: Flora- og vegetasjonsundersøkelser på Barentsøya. (Investigations of flora and vegetation on Barentsøya.) MAB i Norge-Svalbardprosjektet. Rapp. 8 . Oslo.

Hofmann, W. \& Thannheiser, D. 1972: Floristische Neufunde von Kross- und Kongsfjord, Spitzbergen. (New floristic discoveries at Krossfjord and Kongsfjord, Spitsbergen.) Polarforschung 42, 122-124.

Högbom, B. 1913: Om Spetsbergens Mytilustid. (On the Mytilus epoch of Spitsbergen.) Geol. Fören. Förhandl. $35,151-155$.

Holmboe, J. 1910: Moden krækling fra Spitsbergen. (Ripe Empetrum from Spitsbergen.) Naturen 34, 380-381.

Holmen, K. 1957: The vascular plants of Peary Land, north Greenland. Medd. Grønl. 124.

Holmgren, P. K., Holmgren, N. H. \& Barnett, L. C. 1990: Index herbariorum. Part I: the herbaria of the world. New York: New York Botanical Garden.

Hultén, E. 1958: The amphi-Atlantic plants and their phytogeographical connections. Kungliga Svenska VetenskapsAkademiens Handlingar. Ser. 4(7).

Hultén, E. 1964: Salix glauca subsp. callicarpaea in Spitsbergen. Sven. Bot. Tidskr. 58, 350.

Hultén, E. 1968: Flora of Alaska and neighboring territories. Stanford: Stanford University Press.

Hultén, E. 1973: Supplement to flora of Alaska and neighboring territories. A study in the flora of Alaska and the transberingian connection. Bot. Not. 126, 459-512.

Hultén, E. \& Fries, M. 1986: Atlas of north European vascular plants north of the Tropic of Cancer. Königstein: Koeltz 
Scientific Books

IUCN (World Conservation Union) 2001: IUCN Red List categories and criteria version 3.1. On the internet at www. redlist.org/info/categories criteria.html.

Jørgensen, C. A., Sørensen, T. \& Westergaard, M. 1958: The flowering plants of Greenland. A taxonomical and cytological study. Biologiske Skrifter Kongelige Danske Videnskabers Selskab 9.

Keilhau, B. M. 1831: Reise i Öst-og Vest-Finmarken samt til Beeren-Eiland $i$ aarene 1827 og 1828. (Travel to eastern and western Finnmark and to Bjørnøya during the years 1827 and 1828.) Christiania (Oslo): Cappelen.

Kuc, M. \& Dubiel, E. 1995: The vascular plants of the Hornsund area (SW Spitsbergen). Fragm. Flor. Geobot. 40, 797-824.

Laane, M. M. 1968: Cyto-ecological studies in Norwegian Campanula-species. Bot. Tidsskr. 63, 319-334.

Lid, J. 1925: Four new phanerogams from Svalbard (Spitsbergen). Nyt Magazin for Naturvidenskaberne 63, 315-316.

Lid, J. 1962: Stutt-arve funnen på Svalbard. (Sagina caespitosa found in Svalbard.) Blytia 20, 100-101.

Lid, J. 1964: The flora of Jan Mayen. Nor. Polarinst. Skr. 130.

Lid, J. 1967: Synedria of twenty vascular plants from Svalbard. Bot. Jahrb. 86, 481-493.

Lynge, B. 1924: Vascular plants from Novaya Zemlya. Report of the scientific results of the Norwegian expedition to Novaya Zemlya 1921. No. 13. Kristiania (Oslo): Videnskapsselskapet.

Major, H. \& Nagy, J. 1966: Geology of the Adventdalen area. With geological map, Svalbard C9G, 1:100 000. Nor. Polarinst. Skr. 138.

Malmgren, A. J. 1862: Öfversigt af Spetsbergens fanerogamflora. (Survey of the phanerogamic flora of Spitsbergen.) Öfversigt Kungliga Vetenskaps-Akademiens Förhandlingar 1862, 229-268.

Michelmore, A. P. G. 1934: Botany of the Cambridge expedition to Edge Island, S.E. Spitsbergen, in 1927. J. Ecol. 22, 156-176.

Miljøverndepartementet 2003: Mest omfattende vern på 30 år sikrer Svalbards unike natur. (The most comprehensive protection in 30 years safeguards the unique nature of Svalbard.) Press release 26/09/03. Oslo: Ministry of the Environment. Available on the internet at http:/odin.dep.no/ md/norsk/tema/svalbard/arkiv/022021-070159/indexdok000-b-n-a.html.

Misund, S. 1997: Germination and growth in Betula nana $L$. from Spitsbergen and Tromsø. Cand. scient. thesis, University of Tromsø.

Möller, I. 2000: Pflanzensoziologische und vegetationsökologische Studien in Nordwestspitzbergen. (Phytosociological and vegetation ecological studies in northwestern Spitsbergen.) Mitt. Geogr. Ges. Hamb. 90

Möller, I. \& Thannheiser, D. 1997: Eine V $\backslash$ vegetationsoase im unteren Mimerdalen am Billefjord, Zentral-Spitzbergen. (A vegetational oasis at lower Mimerdalen, Billefjord, central Spitsbergen.) Polarforschung 65, 65-70.

Murray, D. F. 1997: Regional and local vascular plant diversity in the Arctic. Opera Bot. 132, 9-18.

Nathorst, A. G. 1871: Om vegetationen på Spetsbergens vestkust. (On the vegetation on the western coast of Spitsbergen.) Bot. Not. 1871, 105-117.

Nathorst, A. G. 1883: Nya bidrag till kännedomen om Spetsbergens kärlväxter, och dess växtgeografiska förhållanden. (New contributions to the knowledge of the vascular plants of Spitsbergen, and their phytogeographical relations.) Kungliga Svenska Vetenskaps-Akademiens Handlingar 20

Neilson, A. H. 1968: Vascular plants from the northern part of Nordaustlandet, Svalbard. Nor. Polarinst. Skr. 143.

Neilson, A. H. 1970: Vascular plants of Edgeøya, Svalbard. Nor. Polarinst. Skr. 150.

Resvoll-Holmsen, H. 1913: Observations botaniques. Exploration de nord-ouest de Spitsberg entreprise sous les auspices de S.A. le Prince de Monaco par la mission Isachsen. (Botanical observations. Exploration of northwestern Spitsbergen performed by the Isachsen expedition, sponsored by H. E. the Prince of Monaco.) Résultats Campagne Scientifique Prince Albert I, 44. Imprimerie de Monaco.

Rønning, O. I. 1961: Some new contributions to the flora of Svalbard. Norsk Polarinst. Skr. 124.

Rønning, O. I. 1972: The distribution of the vascular cryptogams and monocotyledons in Svalbard. Det Kongelige Norske Videnskabers Selskabs Skrifter 24.

Rønning, O. I. 1996: Svalbards flora. (Flora of Svalbard.) Polarhåndbok 9. Oslo: Norwegian Polar Institute.

Rudmose Brown, R. N. 1908: The flora of Prince Charles Foreland, Spitsbergen. Bot. Soc. Edinb. Trans. 23, 313-320.

Schweitzer, H.-J. 1966: Beiträge zur Flora Svalbards. (Contributions to the flora of Svalbard.) Nor. Polarinst. Arb. 1964, 139-148.

Shetler, S. G. 1982: Variation and evolution of the nearctic harebells (Campanula subsect. Heterophylla). Phanerogamarum Monographiae 11. Vaduz, Liechtenstein: J. Cramer.

Simmons, H. G. 1906: The vascular plants in the flora of Ellesmereland. Results of the Norwegian Arctic expeditions in the "Fram" 1898-1902, 2. Kristiania (Oslo): Videnskabs-Selskapet.

Sørensen, T. 1933: The vascular plants of East Greenland from $71^{\circ} 00^{\prime}$ to $73^{\circ} 30^{\prime}$ n. lat. Medd. Grønl. 101.

Spjelkavik, S. 1991: Vegetasjonsundersøkelser langs foreslåtte veitraséer mellom Longyearbyen og Svea. Investigation of vegetation along proposed roads between Longyearbyen and Svea. Nor. Polarinst. Medd. 117, 11-26.

Steffensen, E. 1982: The climate at Norwegian Arctic stations. Klima 5. Oslo: Norwegian Meteorological Institute.

Stortinget 2000: Regjeringens miljøvernpolitikk og rikets miljøtilstand. Stortingsmelding nr. 8, 1999-2000. (Environmental policies of the Government and the environmental state of the Kingdom.) Oslo: Ministry of the Environment. Available on the internet at http://odin.dep.no/ md/norsk/publ/stmeld/022005-040006/index-dok000-bn-a.html.

Summerhayes, V. S. \& Elton, C. S. 1928: Further contributions to the ecology of Spitsbergen. J. Ecol. 16, 193-268.

Sunding, P. 1966: Plantefunn fra Vestspitsbergen sommeren 1964. (Plant finds on Spitsbergen, the summer of 1964.) Nor. Polarinst. Arb. 1964, 149-154.

Thannheiser, D. 1972: Vegetationskartierungen auf der Germaniahalvøya. Vegetation mapping on the Germaniahalvøya. Stuttg. Geogr. Stud. 117, 141-160.

Theisen, F. \& Brude, O. W. 1998: Evaluering av områdevernet på Svalbard. Representativitet og behov for ytterligere vern. (Assessment of the areal protection in Svalbard. Representativity and needs of extended protection.) Nor. Polarinst. Medd. 153

Tolmachev, A. I. 1976: Flora severo-vostoka evropeiskoi časti SSSR II. Cyperaceae-Caryophyllaceae. (Flora of the north-western European parts of the USSR II. Cyperace- 
ae-Caryophyllaceae.) Leningrad: Nauka.

Tolmachev, A. I., Packer, J. G. \& Griffiths, G. C. D. (eds.) 1996: The flora of the Russian Arctic 3: Salicaceae to Ranunculaceae. Edmonton: University of Alberta Press.

Triloff, E. G. 1944: Verbreitung und ökologie der gefässpflanzen im gebiete des Hornsundes: ein beitrag zur vegetationskunde Spitzbergens. (Distribution and ecology of the vascular plants of the Hornsund area: a contribution to the knowledge of the vegetation of Spitsbergen.) Bot. Jahrb. 37, 259-360.

Turnbull, R. 1900: Contributions to the flora of Spitsbergen, especially of Red Bay, from the Collections of W. S. Bruce, F.R.S.G.S., naturalist to the Prince of Monaco's expeditions of 1898 and 1899. Transactions and Proceedings of the Botanical Society of Edinburgh 1900, 352-357.

van der Knaap, W. O. 1987: Five short pollen diagrams of soils from Jan Mayen, Norway: a testimony of a dynamic landscape. Polar Res. 5, 193-206.

van der Knaap, W. O. 1988: A pollen diagram from Brøggerhalvøya, Spitsbergen: changes in vegetation and environment from ca. 4400 to ca. 800 BP. Arct. Alp. Res. 20, 106116.

van der Knaap, W. O. 1989: Past vegetation and reindeer on Edgeøya (Spitsbergen) between c. 7900 and c. 3000 BP studied by means of peat layers and reindeer faecal pellets. J. Biogeogr. 16, 379-394.

Wirén, E. 1922: Iakttagelser under några botaniska exkursioner på Spetsbergen. (Observations during some botanical excursions on Spitsbergen.) Sven. Bot. Tidskr. 16, $363-$ 370 .

Wohlfahrt, B., Lemdahl, G., Olsson, S., Persson, T., Snowball, I., Ising, J. \& Jones, V. 1995: Early Holocene environment on Bjørnøya (Svalbard) inferred from multidisciplinary lake sediment studies. Polar Res. 14, 253-275.

\section{Appendix 1}

The table below lists the locations and population sizes of 20 thermophilous vascular plant species in Svalbard. Localities within established protected areas (Fig. 2) are in boldface. Names of fieldworkers are abbreviated as follows: Inger Greve Alsos-IA; Mari Aasen-MA; Geir ArnesenGA; Liv Borgen-LB; Christian BrochmannCB; Torstein Engelskjøn-TE; Arve ElvebakkAE; Reidar Elven-RE; Ivar Hauge-IH; Kjell Tor Hansen-KH; Leidulf Lund-LL; Arne Pedersen-
AP; Olaf I. Rønning-OR; Hanna Resvoll-Dieset/ Resvoll-Holmsen-HR; Sigmund Spjelkavik-SS; Bjørn Erik Sandbakk-BS; Hans-Joachim Schweitzer-HS; Jan Thomas Schwenke-JS; Ola Skifte-OS; Kristine Westergaard-KW. Years following fieldworkers' names indicate when plant populations were located. Names followed by years in parentheses refer to sources in the reference list. See Table 5 for abbreviations of herbaria. Population sizes (see Table 1) are large-L; medium-M; small-S. Nd stands for no data and $\sum$ is sum.

\begin{tabular}{|c|c|c|c|c|c|c|c|}
\hline \multirow{2}{*}{$\begin{array}{l}\text { Species } \\
\text { Part of Svalbard }\end{array}$} & \multirow[b]{2}{*}{ Location } & \multirow[b]{2}{*}{ Source, herbaria with voucher specimens } & \multicolumn{5}{|c|}{ Population sizes } \\
\hline & & & $\mathrm{L}$ & M & $\mathrm{S}$ & $\mathrm{Nd}$ & $\Sigma$ \\
\hline \multicolumn{8}{|c|}{ Alchemilla glomerulans } \\
\hline \multirow[t]{2}{*}{ Bjørnøya } & SE of Herwighamna & TE 1983, TROM; TE (1987) & & & 1 & & 1 \\
\hline & & Total & & & 1 & & 1 \\
\hline \multicolumn{8}{|l|}{ Betula nana } \\
\hline \multirow[t]{13}{*}{ Nordenskiöld Land } & $\begin{array}{l}\text { Rusanovodden towards } \\
\text { Colesbukta }\end{array}$ & Nathorst 1882, O; IA \& LL 1998; IA, LL et al. (2002) & 1 & 1 & & & 2 \\
\hline & Colesbukta, W, S sides & Strandwitz 1930, TROM; TE \& SS (1999) & 1 & 2 & 5 & 1 & 9 \\
\hline & Colesbukta, E, $\mathrm{N}$ sides & $\begin{array}{l}\text { Fries (1869); TE \& SS 1986; TROM; IA, TE, LL, BS \& } \\
\text { MA 1998; IA \& BS } 1999\end{array}$ & & 1 & 2 & & 3 \\
\hline & Colesdalen, $\mathrm{N}$ side & $\begin{array}{l}\text { TE \& SS 1986, TROM; IA \& LL 1998; IA \& BS 1999, } \\
\text { IA, LL et al. (2002) }\end{array}$ & 1 & 3 & 3 & & 7 \\
\hline & Colesdalen, interior & TE \& SS 1986, $\underline{\text { TROM }}$ & 1 & & & & 1 \\
\hline & Fardalen & LL 1997 & & 1 & 1 & & 2 \\
\hline & Grønfjorddalen & AE (1990) & & & & 1 & 1 \\
\hline & Hotellneset & Vogt $1928, \underline{\mathrm{O}}$ & & & & 1 & 1 \\
\hline & Endalen & OS 1988, TROM; IA, TE, LL, BS \& MA 1998 & & & 1 & & 1 \\
\hline & Todalen & TE \& AP 1970, $\underline{\text { TROM }}$ & & 1 & & & 1 \\
\hline & Janssonhaugen & TE $1970, \underline{\text { TROM }}$ & & 1 & & & 1 \\
\hline & Adventdalen, $\mathrm{N}$ side & $\begin{array}{l}\text { Högbom (1913); Hadač (1944); Sunding (1966); Lid } \\
\text { (1967); TE \& SS 1986, TROM; IA \& LL } 1998\end{array}$ & 1 & 3 & 6 & & 10 \\
\hline & & Total & 5 & 13 & 18 & 3 & 39 \\
\hline
\end{tabular}




\begin{tabular}{|c|c|c|c|c|c|c|c|}
\hline Species & & & Pop & dlati & ion $\mathrm{s}$ & izes & \\
\hline Part of Svalbard & Location & Source, herbaria with voucher specimens & $\mathrm{L}$ & M & $\mathrm{S}$ & $\mathrm{Nd}$ & $\Sigma$ \\
\hline Calamagrostis stricta & & & & & & & \\
\hline Bjørnøya & Dispersed on plain & TE (1987) & & 10 & 9 & 7 & 26 \\
\hline Sørkapp Land & Hornsund, S side & Dubiel 1985, TROM & & & & 1 & 1 \\
\hline Wedel Jarlsberg Land & Hornsund, $\mathrm{N}$ side & Triloff (1944) & & & & 2 & 2 \\
\hline & $\begin{array}{l}\text { Recherchefjorden } \\
\text { Dunderbukta }\end{array}$ & OR \& OS 1960, $\underline{\text { TROM }}$ & & & & 2 & 2 \\
\hline Nathorst Land & Midterhuken & TE et al. (1972) & & & & 1 & 1 \\
\hline & Akseløya & TE et al. (1972) & & & 1 & & 1 \\
\hline Nordenskiöld Land & Bellsund, Berzeliusdalen & $\begin{array}{l}\text { Dahl \& Hadač (1946); TE \& AP 1970; TE \& JS } 1987, \\
\text { TROM }\end{array}$ & & 1 & 2 & 3 & 6 \\
\hline & Reindalen & TE \& AP 1970; CB \& TE 1985; TE \& SS 1986, TROM & & 3 & 4 & & 7 \\
\hline & De Geerdalen & Hadač (1944); TE 1970 & 1 & 5 & & & 6 \\
\hline & $\begin{array}{l}\text { Adventfjorden, Advent- } \\
\text { dalen, tributaries }\end{array}$ & $\begin{array}{l}\text { Hadač (1944); TE \& AP 1970; TE \& SS 1986; TE } 1995 \text {, } \\
\text { 1996, TROM }\end{array}$ & 10 & 5 & 1 & 10 & 26 \\
\hline & Bjørndalen & Asplund (1919); IA, BS 2003, $\underline{\mathrm{O}}$ & & 1 & & & 1 \\
\hline & Colesbukta, Colesdalen & TE \& SS 1986, TROM; IA, LL et al. (2002) & 1 & 8 & 3 & 1 & 13 \\
\hline & Russekeila, Kapp Linné & Dahl \& Hadač (1946) & & & & 2 & 2 \\
\hline Sabine Land & Sassendalen, $\mathrm{N}$ side & RE \& JS 1986, TROM & & & & 1 & 1 \\
\hline Bünsow Land & Bjonadalen & Asplund (1919) & & & & 1 & 1 \\
\hline Dickson Land & Kapp Thordsen & Dahl \& Hadač (1946) & & & & 2 & 2 \\
\hline & Hugindalen & Lid (1967) & & & & 1 & 1 \\
\hline & Oxaasfjellet & Rønning (1972) & & & & 1 & 1 \\
\hline James I Land & Kapp Wærn & Nathorst (1883) & & & & 1 & 1 \\
\hline Oscar II Land & Bohemanneset & Lid 1924; Hadač 1939, $\underline{\mathrm{O}}$ & & & & 1 & 1 \\
\hline Haakon VII Land & Blomstrandhalvøya & OR \& OS 1958, TROM & & & & 1 & 1 \\
\hline & Kongsfjorden, E side & AE (1989); IA 1993 & & & 1 & 2 & 3 \\
\hline & Liefdefjorden, S, W & AE (1989); Möller (2000) & & & & 2 & 2 \\
\hline & & Total & 12 & 33 & 21 & 43 & 108 \\
\hline Campanula rotundifoli & & & & & & & \\
\hline Nordenskiöld Land & Colesdalen, NE side & 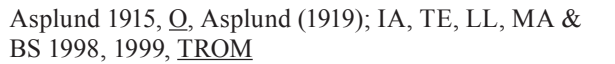 & & & 1 & & 1 \\
\hline & Colesdalen, $\mathrm{N}$ side & $\begin{array}{l}\text { TE \& SS 1986; LL 1997; IA, LL \& BS 1998, TROM; } \\
\text { IA \& BS 1999; IA, LL et al. (2002) }\end{array}$ & 1 & & 1 & & 2 \\
\hline & $\begin{array}{l}\text { Colesbukta towards } \\
\text { Rusanovodden }\end{array}$ & IA, LL et al. (2002) & & & 1 & & 1 \\
\hline & & Total & 1 & & 3 & & 4 \\
\hline Carex marina ssp. pset & udolagopina & & & & & & \\
\hline Nordenskiöld Land & Sassendalen, S side & AE \& Eriksen 1988, TROM & & & & 1 & 1 \\
\hline Sabine Land & Sassendalen, N side & $\begin{array}{l}\text { Nathorst 1882, } \underline{\mathrm{C}} \text {; HS (1966); RE et al. 1986-89, } \underline{\mathrm{O}} \text {, } \\
\underline{\text { TROM }}\end{array}$ & & & & 6 & 6 \\
\hline Bünsow Land & Gipsdalen & CB, TE, AE \& RE 1985; Eriksen 1987, $\underline{\text { O, TROM }}$ & 1 & 1 & 5 & & 7 \\
\hline Dickson Land & Kapp Thordsen & Dahl 1981, pers. comm. 1984 & & & & 1 & 1 \\
\hline Haakon VII Land & Liefdefjorden & Thannheiser (1972) & & & & 1 & 1 \\
\hline & & Total & 1 & 1 & 5 & 9 & 16 \\
\hline Empetrum nigrum ssp. & hermaphroditum & & & & & & \\
\hline Wedel Jarlsberg Land & Recherchefjorden & Lynge $1926, \underline{\mathrm{O}}$ & & & & 1 & 1 \\
\hline & Observatoriefjellet & Elvebakk, pers. comm. 2002 & & & & 1 & 1 \\
\hline Nathorst Land & $\begin{array}{l}\text { Van Keulenfjorden, } \\
\text { Annahamna }\end{array}$ & Lynge $1926, \underline{\mathrm{O}}$ & & & & 1 & 1 \\
\hline & $\begin{array}{l}\text { Van Keulenfjorden, } \\
\text { Louisefjellet }\end{array}$ & Lid $1920, \underline{\mathrm{O}}$ & & 1 & & & 1 \\
\hline Nordenskiöld Land & Bellsund & OR \& OS 1958, $\underline{\text { TROM }}$ & & & 2 & 1 & 3 \\
\hline & Berzeliusdalen & TE, AP \& HS 1970, TROM & & & 1 & & 1 \\
\hline
\end{tabular}




\begin{tabular}{|c|c|c|c|c|c|c|c|}
\hline \multirow{2}{*}{$\begin{array}{l}\text { Species } \\
\text { Part of Svalbard }\end{array}$} & \multirow[b]{2}{*}{ Location } & \multirow[b]{2}{*}{ Source, herbaria with voucher specimens } & \multicolumn{5}{|c|}{ Population sizes } \\
\hline & & & $\mathrm{L}$ & M & $\mathrm{S}$ & $\mathrm{Nd}$ & $\Sigma$ \\
\hline & $\begin{array}{l}\text { Van Mijenfjorden, N, } \\
\text { W, Camp Morton area, } \\
30-40 \mathrm{~m} \text { asl }\end{array}$ & Holmboe (1910); AE \& Hodin 1986, TROM & & & 3 & & 3 \\
\hline & Reindalen, tributaries & TE et al. (1972); CB, TE 1985, TROM; SS (1991) & 1 & 3 & 3 & 1 & 8 \\
\hline & Lundströmdalen & SS (1991) & & & & 1 & 1 \\
\hline & Van Mijenfjorden, $\mathrm{N}$ & TE et al. (1972) & & & 1 & & 1 \\
\hline & Grønfjorden area & Fries (1869), Asplund (1919), Wirén (1922) & & & & 1 & 1 \\
\hline & Hollendardalen & Sunding (1966) & & & & 1 & 1 \\
\hline & Colesbukta, both sides & $\begin{array}{l}\text { TE \& SS 1986, TROM; TE \& SS (1999); IA, TE, LL, } \\
\text { BS \& MA 1998; IA \& KW } 2002\end{array}$ & & 3 & 2 & 2 & 7 \\
\hline & Colesdalen, $\mathrm{N}$ side & $\begin{array}{l}\text { TE \& SS 1986, TROM; TE \& SS (1999), IA \& SS } \\
\text { 1999; IA, LL et al. (2002) }\end{array}$ & & 1 & 4 & & 5 \\
\hline & $\begin{array}{l}\text { Adventfjorden, } \\
\text { Adventdalen, tributaries }\end{array}$ & $\begin{array}{l}\text { Nathorst (1883); Hadač (1944); Sunding (1966), TE \& } \\
\text { AP 1970; GA \& TE 1996, TROM; IA \& LL } 1998\end{array}$ & & 4 & 1 & 1 & 6 \\
\hline \multirow[t]{4}{*}{ Dickson Land } & $\begin{array}{l}\text { Mimerdalen and } \\
\text { Pyramiden }\end{array}$ & $\begin{array}{l}\text { Nathorst (1883); Högbom (1913); Möller, Thannheiser } \\
\text { (1997); IA \& LL } 1998\end{array}$ & 1 & & & & 1 \\
\hline & Odindalen & RE 1990, TROM & & & 1 & & 1 \\
\hline & Kapp Wijk & Ballye $1896, \underline{C G E}$ & & & & 1 & 1 \\
\hline & Kapp Thordsen $75 \mathrm{~m}$ asl & RE 1992, TROM & & & & 1 & 1 \\
\hline James I Land & $\begin{array}{l}\text { Ekmanfjorden, Kapp } \\
\text { Wærn }\end{array}$ & Fries (1869); Asplund (1919) & & & & 3 & 3 \\
\hline \multirow[t]{5}{*}{ Oscar II Land } & Bohemanneset & Andersson \& Hesselman (1900) & & & & 1 & 1 \\
\hline & St. Jonsfjorden area & Iversen \& Koefoed 1923, $\underline{\mathrm{BG}}, \underline{\mathrm{O}}$ & & & & 1 & 1 \\
\hline & Ymerbukta & Nathorst (1883) & & & & 1 & 1 \\
\hline & Bertilfjellet & Asplund (1919) & & & & 1 & 1 \\
\hline & Kongsfjorden area & $\begin{array}{l}\text { Hofmann \& Thannheiser (1972); Möller (2000); AE \& } \\
\text { SS (1995) }\end{array}$ & 4 & 2 & 1 & 1 & 8 \\
\hline \multirow[t]{2}{*}{ Haakon VII Land } & $\begin{array}{l}\text { Liefdefjorden, } \\
\text { Lernerøyane }\end{array}$ & Thannheiser (1972); AE \& SS (1995); Möller (2000) & 2 & $\sim 10$ & & & $\sim 12$ \\
\hline & Raudfjorden & Iversen \& Koefoed 1923, $\underline{\mathrm{O}}$ & & & & 1 & 1 \\
\hline \multirow[t]{3}{*}{ Albert I Land } & Smeerenburgfjorden & Solheim et al. 1936, $\underline{\mathrm{O}}$ & & & & 1 & 1 \\
\hline & Krossfjorden, W side & Hjelle 1964, $\underline{\mathrm{O}}$ & & & 1 & & 1 \\
\hline & Krossfjorden, E side & Hofmann \& Thannheiser (1972); AE \& S (1995) & & & & 2 & 2 \\
\hline \multirow[t]{2}{*}{ Ny-Friesland } & Wijdefjorden, E side & Summerhayes \& Elton (1928) & & & & 1 & 1 \\
\hline & Mosselbukta & Spicer $1964, \underline{\mathrm{O}}$ & & & & 1 & 1 \\
\hline Gustav V Land & $\begin{array}{l}\text { Nordaustlandet, } \\
\text { Depotodden }\end{array}$ & Brattbakk (1981, cited in AE \& SS 1995) & & & & 1 & 1 \\
\hline & & Total & 8 & 14 & 30 & 28 & $\sim 80$ \\
\hline \multicolumn{8}{|l|}{ Euphrasia frigida } \\
\hline \multirow[t]{2}{*}{ Nordenskiöld Land } & Colesdalen & IA \& LL 1998, TROM, IA \& LL (1999); IA \& BS 1999 & & & 3 & & 3 \\
\hline & Colesbukta, E side & IA, LL et al. (2002) & & & 2 & & 2 \\
\hline \multirow[t]{3}{*}{ Haakon VII Land } & $\begin{array}{l}\text { Bockfjorden, } \\
\text { Trollkjeldene }\end{array}$ & OS 1960, TROM, OR (1961) & & & 1 & & 1 \\
\hline & Ossian Sarsfjellet & KH, IA, BS 2003, TROM & & & 1 & & 1 \\
\hline & & Total & & & 7 & & 7 \\
\hline \multicolumn{8}{|l|}{ Hippuris vulgaris } \\
\hline \multirow[t]{3}{*}{ Bjørnøya } & $\mathrm{N}$ side, plain & E (1986a) & 2 & 7 & 6 & & 15 \\
\hline & $\mathrm{W}$ and $\mathrm{SW}$ sides, plain & E (1986a) & & 3 & 4 & & 7 \\
\hline & & Total & 2 & 10 & 10 & & 22 \\
\hline \multicolumn{8}{|l|}{ Juncus castaneus } \\
\hline \multirow[t]{2}{*}{ Nordenskiöld Land } & Longyeardalen & Lid $1924, \underline{\mathrm{O}}$ & & & & 1 & 1 \\
\hline & De Geerdalen & HS (1966) & & & & 1 & 1 \\
\hline Sabine Land & Sassendalen & Nathorst (1883) & & & & 1 & 1 \\
\hline
\end{tabular}




\begin{tabular}{|c|c|c|c|c|c|c|c|}
\hline \multirow{2}{*}{$\begin{array}{l}\text { Species } \\
\text { Part of Svalbard }\end{array}$} & \multirow[b]{2}{*}{ Location } & \multirow[b]{2}{*}{ Source, herbaria with voucher specimens } & \multicolumn{5}{|c|}{ Population sizes } \\
\hline & & & $\mathrm{L}$ & M & $\mathrm{S}$ & $\mathrm{Nd}$ & $\Sigma$ \\
\hline & Gjelhallet & Dahl 1981, $\underline{\mathrm{O}}$ & & & & 1 & 1 \\
\hline \multirow[t]{2}{*}{ Bünsow Land } & Gipsdalen & Eriksen 1987, $\underline{\mathrm{O}}, \underline{\mathrm{TROM}}$; RE et al. (1990) & & & 1 & & 1 \\
\hline & & Total & & & 1 & 4 & 5 \\
\hline \multicolumn{8}{|l|}{ Juncus triglumis } \\
\hline Wedel Jarlsberg Land & Recherchefjorden & Turnbull (1900) & & & & 1 & 1 \\
\hline \multirow[t]{3}{*}{ Nordenskiöld Land } & Sassenfjorden, S side & Hadač (1944) & & & & 1 & 1 \\
\hline & Adventdalen & Hadač (1944); TE, SS 1986, TROM & & 2 & 1 & 6 & 9 \\
\hline & Bjørndalen & HR (1913) & & & & 1 & 1 \\
\hline Sabine Land & Sassendalen & Nathorst (1883); RE et al. 1986, TROM & & & 1 & 5 & 6 \\
\hline Bünsow Land & Gipsdalen & CB, TE, AE, RE 1985, TROM & & 2 & 1 & 1 & 4 \\
\hline Dickson Land & $\begin{array}{l}\text { Mimerdalen to } \\
\text { Dicksonfjorden }\end{array}$ & Lid 1924; Lid (1925); RE 1990, $\underline{\text { O, TROM }}$ & & & 1 & 5 & 6 \\
\hline \multirow[t]{2}{*}{ Haakon VII Land } & Ossian Sarsfjellet & AE 1988, TROM & & & & 2 & 2 \\
\hline & Blomstrandhalvøya & AE $1988, \underline{\text { TROM }}$ & & & & 1 & 1 \\
\hline Andrée Land & Purpurdalen & Dahl, Hadač (1946) & & & & 1 & 1 \\
\hline \multirow[t]{3}{*}{ Ny-Friesland } & Austfjordnes & Spicer 1964, TROM & & & 1 & & 1 \\
\hline & Wijdefjorden, E side & AE 2002, pers. comm. 2002 & & & & 6 & 6 \\
\hline & & Total & & 4 & 5 & 30 & 39 \\
\hline \multicolumn{8}{|l|}{ Kobresia simpliciuscula } \\
\hline Bünsow Land & Gipsdalen & TE 1985, TROM; TE (1986b) & & & 1 & & 1 \\
\hline \multirow[t]{2}{*}{ Dickson Land } & Mimerdalen & Isachsen 1925, $\underline{\mathrm{O}}$; Høeg 1928, $\underline{\mathrm{TRH}}$ & & & & 1 & 1 \\
\hline & Adolfbukta & AE 2001, pers. comm. 2001 & & & 1 & & 1 \\
\hline Haakon VII Land & Kongsfjorden & AE 1988, TROM (1993) & & 1 & 1 & & 2 \\
\hline \multirow[t]{2}{*}{ Ny-Friesland } & Wijdefjorden, E side & AE 2002, pers. comm. 2002 & & & & 3 & 3 \\
\hline & & Total & & 1 & 3 & 4 & 8 \\
\hline \multicolumn{8}{|l|}{ Luzula wahlenbergii } \\
\hline Nathorst Land & Bromelldalen & Lynge 1926, $\underline{\mathrm{O}}$ & & & & 1 & 1 \\
\hline \multirow[t]{5}{*}{ Nordenskiöld Land } & Berzeliusdalen & TE, AP 1970; TE \& JS 1987, TROM & & & 2 & & 2 \\
\hline & Reindalen, tributaries & 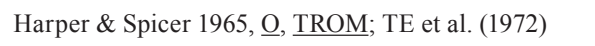 & & & 3 & 2 & 5 \\
\hline & $\begin{array}{l}\text { Adventfjorden, Bjørn- } \\
\text { dalen, Revneset, } \\
\text { Longyearbyen }\end{array}$ & $\begin{array}{l}\text { Nathorst (1883); TE \& HS 1970, TROM; Spicer } 1965 \text {, } \\
\text { TROM; Brosø 1996, TROM }\end{array}$ & & 1 & 2 & 2 & 5 \\
\hline & Colesdalen & TE \& SS 1986, TROM & & & 1 & & 1 \\
\hline & & Total & & 1 & 8 & 5 & 14 \\
\hline \multicolumn{8}{|l|}{ Ranunculus arcticus } \\
\hline Edgeøya & Western coast & Neilson (1970) & & 1 & & & 1 \\
\hline Sørkapp Land & Sørkapp & Kristoffersen 1930, TROM & & & & 1 & 1 \\
\hline Nathorst Land & Midterhuken to Bellsund & Malmgren 1864, $\underline{\mathrm{O}}$; TE et al. (1972) & & & 1 & 1 & 2 \\
\hline \multirow[t]{2}{*}{ Nordenskiöld Land } & Kolfjellet & TE et al. (1972); AE et al. (1987) & & & 1 & & 1 \\
\hline & De Geerdalen, outlet & Hadač (1944) & & & & 2 & 2 \\
\hline Sabine Land & Sassendalen, outlet, $\mathrm{N}$ & RE 1986, TROM & & & & 2 & 2 \\
\hline Bünsow Land & $\begin{array}{l}\text { Gipsdalen, } \\
\text { Tempelfjorden }\end{array}$ & TE, CB, AE, RE \& Hodin 1985, TROM & & 1 & 8 & & 9 \\
\hline Dickson Land & $\begin{array}{l}\text { Kapp Thordsen, } \\
\text { surroundings }\end{array}$ & HR 1908, O; RE, AE (1996) & & & & 4 & 4 \\
\hline Oscar II Land & Alkhornet & HR $1908, \underline{\mathrm{O}}$; OR, OS 1958, $\underline{\text { TROM }}$ & & & & 1 & 1 \\
\hline \multirow[t]{3}{*}{ Haakon VII Land } & Krossfjorden & Malmgren (1862) & & & & 1 & 1 \\
\hline & Ossian Sarsfjellet & AE 1999, TROM; IA, KH, BS 2003, $\underline{\text { TROM }}$ & & 1 & & & 1 \\
\hline & & Total & & 3 & 10 & 12 & \\
\hline \multicolumn{8}{|l|}{ Ranunculus lapponicus } \\
\hline Nathorst Land & Bromelldalen & TE et al. 1970, TROM; TE et al. (1972) & & & 1 & & 1 \\
\hline
\end{tabular}




\begin{tabular}{|c|c|c|c|c|c|c|c|}
\hline \multirow{2}{*}{$\begin{array}{l}\text { Species } \\
\text { Part of Svalbard }\end{array}$} & \multirow[b]{2}{*}{ Location } & \multirow[b]{2}{*}{ Source, herbaria with voucher specimens } & \multicolumn{5}{|c|}{ Population sizes } \\
\hline & & & $\mathrm{L}$ & M & $\mathrm{S}$ & $\mathrm{Nd}$ & $\Sigma$ \\
\hline \multirow[t]{7}{*}{ Nordenskiöld Land } & $\begin{array}{l}\text { Van Mijenfjorden, N } \\
\text { Reindalen, Gangdalen }\end{array}$ & $\begin{array}{l}\text { Lynge 1926; Harper 1964, O; TE et al. (1972); CB \& } \\
\text { TE 1985, TROM; AE } 1986\end{array}$ & 1 & 8 & 5 & & 14 \\
\hline & De Geerdalen, E, W sides & Hadač (1944); TE 1970; RE 1987, TROM & & & 2 & 6 & 8 \\
\hline & Eskerdalen & Hadač (1944) & & & & 1 & 1 \\
\hline & Brentskardet & Hadač (1944) & & & & 1 & 1 \\
\hline & $\begin{array}{l}\text { Revneset to Adventdalen, } \\
\text { tributaries }\end{array}$ & $\begin{array}{l}\text { Nathorst 1868, } \underline{\mathrm{O}} \text {; Hadač (1944); Lid (1967); TE \& AP } \\
\text { 1970; TE \& SS 1986; TE 1987, TROM }\end{array}$ & & 6 & 1 & 5 & 12 \\
\hline & Bjørndalen & Sunding $1960, \underline{O}$ & & & & 1 & 1 \\
\hline & Colesbukta, Colesdalen & $\begin{array}{l}\text { RH 1908, O; E \& S 1986, TROM; AE 1986, IA, LL et } \\
\text { al. (2002) }\end{array}$ & 1 & 2 & 1 & 11 & 15 \\
\hline Sabine Land & Sassendalen, $N$ side & $\begin{array}{l}\text { Asplund 1915, O; RE \& JS 1986, TROM; AE \& } \\
\text { Øvstedal 1987, } \underline{\text { TROM }}\end{array}$ & & & & 4 & 4 \\
\hline Dickson Land & $\begin{array}{l}\text { Kapp Thordsen, Kapp } \\
\text { Wijk }\end{array}$ & $\begin{array}{l}\text { Wilander \& Nathorst 1870, } \underline{\mathrm{O}} \text {; Foged 1958, TROM; RE } \\
\text { 1990, } \underline{\mathrm{O}}, \underline{\text { TROM }}\end{array}$ & & 5 & 4 & 1 & 10 \\
\hline Oscar II Land & Bohemanneset & Wirén (1922); Lid 1924, $\underline{\mathrm{O}}$ & & & & 1 & 1 \\
\hline Haakon VII Land & Feiringfjell $5 \mathrm{~m}$ asl & I. Brattbakk 1974, $\underline{\text { TRH }}$ & & & & 1 & 1 \\
\hline \multirow[t]{2}{*}{ Ny-Friesland } & At Wijdefjorden & Nathorst (1883) & & & & 1 & 1 \\
\hline & & Total & 2 & 21 & 14 & 33 & 70 \\
\hline \multicolumn{8}{|l|}{ Ranunculus pallasii } \\
\hline \multirow[t]{5}{*}{ Nordenskiöld Land } & $\begin{array}{l}\text { Stormyra, below } \\
\text { Høgsnyta }\end{array}$ & TE, AP 1970, TROM; TE et al. (1972) & & 1 & & & 1 \\
\hline & Reindalssletta & TE $1985, \underline{\text { TROM }}$ & & 3 & & & 3 \\
\hline & $\begin{array}{l}\text { Adventfjorden, } \\
\text { Adventdalen }\end{array}$ & Lid 1924, O; OR 1959, TROM; HS (1966) & & 1 & & 3 & 4 \\
\hline & Kapp Laila & TE 1986, TROM & & & 1 & & 1 \\
\hline & Colesdalen, interior & TE \& SS (1999) & & & 1 & & 1 \\
\hline \multirow[t]{2}{*}{ Oscar II Land } & Bohemanflya & Lid 1924, O; RE, Andersen 1997, TROM & 1 & & & & 1 \\
\hline & & Total & 1 & 5 & 2 & 3 & 11 \\
\hline \multicolumn{8}{|l|}{ Ranunculus wilanderi } \\
\hline \multirow[t]{2}{*}{ Dickson Land } & Kapp Thordsen & Jørgensen 1896, O; GA \& TE 1996 & & & 1 & & 1 \\
\hline & & Total & & & 1 & & 1 \\
\hline \multicolumn{8}{|l|}{ Rhodiola rosea } \\
\hline Bjørnøya & Mainly $\mathrm{N}$ and $\mathrm{E}$ coast & TE (1987) & 2 & 4 & 20 & 2 & 28 \\
\hline \multirow[t]{3}{*}{ Prins Karls Forland } & Central, south & Rudmose Brown (1908) & & & 1 & & 1 \\
\hline & Richardlaguna & Rønning, pers. comm. 1985 & & & & 1 & 1 \\
\hline & & Total & 2 & 4 & 21 & 3 & 30 \\
\hline \multicolumn{8}{|l|}{ Rubus chamaemorus } \\
\hline \multirow[t]{3}{*}{ Nordenskiöld Land } & Rusanovodden & Nathorst (1883); IA \& LL 1998 & & 1 & & & 1 \\
\hline & SE of Rusanovodden & IA, LL et al. (2002) & & 1 & & & 1 \\
\hline & Colesdalen, Tenndammen & $\begin{array}{l}\text { Asplund 1915, O, Asplund (1919); Nilsen 1979, TROM; } \\
\text { IA \& LL } 1998\end{array}$ & & & 1 & & 1 \\
\hline Sabine Land & Sassendalen & HR (1913) & & & & 1 & 1 \\
\hline Dickson Land & Kapp Thordsen & RE, LB 1992, TROM; GA, TE \& RE 1996 & & 1 & & 1 & 2 \\
\hline \multirow[t]{3}{*}{ James I Land } & $\begin{array}{l}\text { Ekmanfjorden, W side: } \\
\text { below Ekmanfjellet, } \\
\text { Hemsil river }\end{array}$ & $\begin{array}{l}\text { Nathorst (1883); Wirén (1922); Nilsen 1979, TROM; IA } \\
\text { \& LL } 1998\end{array}$ & & & 2 & & 2 \\
\hline & Sveaneset & Wirén (1922); IH 1998, pers. comm. 1998 & & 1 & & & 1 \\
\hline & & Total & & 4 & 3 & 2 & 9 \\
\hline \multicolumn{8}{|l|}{ Salix lanata } \\
\hline Nordenskiöld Land & $\begin{array}{l}\text { Adventdalen N, WSW of } \\
\text { Innerhytta, ca. } 70 \mathrm{~m} \text { asl }\end{array}$ & $\begin{array}{l}\text { HS 1963, O, SS; HS 1964, TROM; HS (1966); Hultén } \\
\text { (1964); TE \& SS 1986; IA \& LL 1998, TROM; LL } 2001\end{array}$ & & & 1 & & 1 \\
\hline Oscar II Land & $\begin{array}{l}\text { Ny-Ålesund, at Storvatn, } \\
40 \text { m asl (extirpated } \\
1990-91 \text { ) }\end{array}$ & $\begin{array}{l}\text { Aasgaard \& OR 1974; OR 1991, TRH; AE 1976, pers. } \\
\text { comm. } 2002\end{array}$ & & & 1 & & 1 \\
\hline
\end{tabular}




\begin{tabular}{|c|c|c|c|c|c|c|}
\hline Species & \multirow[b]{2}{*}{ Location } & \multirow[b]{2}{*}{ Source, herbaria with voucher specimens } & \multicolumn{4}{|c|}{ Population sizes } \\
\hline Part of Svalbard & & & $\mathrm{L}$ & M & $\mathrm{S} \mathrm{Nd}$ & $\Sigma$ \\
\hline & & Total & & & 2 & 2 \\
\hline \multicolumn{7}{|c|}{ Vaccinium uliginosum } \\
\hline \multirow[t]{3}{*}{ Nordenskiöld Land } & Colesdalen & $\begin{array}{l}\text { Holmsen 1912, O; Finnseth 1936, TROM; LL } 1997 \\
\text { (photo); IA, LL, BS, MA 1998, TROM; IA, BS } 1999\end{array}$ & & 1 & & 1 \\
\hline & $\begin{array}{l}\text { Colesbukta towards } \\
\text { Rusanovodden }\end{array}$ & IA; LL et al. (2002) & & 1 & & 1 \\
\hline & Kreklingpasset & Egge 1940, 1941, $\underline{\mathrm{O}}$; Nilsen 1981, TㅁM & & & 1 & 1 \\
\hline \multirow[t]{3}{*}{ Dickson Land } & Mimerdalen & $\begin{array}{l}\text { Högbom (1913); Høeg 1928, TRH; Möller \& } \\
\text { Thannheiser (1997) }\end{array}$ & & & 1 & 1 \\
\hline & Idodalen & IA \& LL 1998, TROM & & & 1 & 1 \\
\hline & & Total & & 2 & 3 & 5 \\
\hline
\end{tabular}

